NBER WORKING PAPER SERIES

\title{
STRIKES, SCABS AND TREAD SEPARATIONS: \\ LABOR STRIFE AND THE PRODUCTION \\ OF DEFECTIVE BRIDGESTONE/FIRESTONE TIRES
}

\author{
Alan B. Krueger \\ Alexandre Mas \\ Working Paper 9524 \\ http://www.nber.org/papers/w9524 \\ NATIONAL BUREAU OF ECONOMIC RESEARCH \\ 1050 Massachusetts Avenue \\ Cambridge, MA 02138 \\ February 2003
}

We are grateful to Colin Cameron, David Card, Henry Farber, Seth Harris, Alain Kornhauser, Paul Rosenbaum, Chris Sims, Jim Sturm and seminar participants at Princeton University, Stanford Law School, U.C. Berkeley, MIT, the NBER, the Biennial Hong Kong Economic Association Meeting, and the University of Pennsylvania for helpful comments. The views expressed herein are those of the author and not necessarily those of the National Bureau of Economic Research.

(C)2003 by Alan B. Krueger and Alexandre Mas. All rights reserved. Short sections of text not to exceed two paragraphs, may be quoted without explicit permission provided that full credit including Cnotice, is given to the source. 
Strikes, Scabs and Tread Separations: Labor Strife and the Production of Defective Bridgestone/Firestone Tires

Alan B. Krueger and Alexandre Mas

NBER Working Paper No. 9524

February 2003

JEL No. J5, M1, M5

\begin{abstract}
$\underline{\text { ABSTRACT }}$
This paper provides a case study of the effect of labor relations on product quality. We consider whether a long, contentious strike and the hiring of permanent replacement workers by Bridgestone/Firestone in the mid-1990s contributed to the production of an excess number of defective tires. Using several independent data sources we find that labor strife in the Decatur plant closely coincided with lower product quality. Count data regression models based on two data sets of tire failures by plant, year and age show significantly higher failure rates for tires produced in Decatur during the labor dispute than before or after the dispute, or than at other plants. Also, an analysis of internal Firestone engineering tests indicates that P235 tires from Decatur performed less well if they were manufactured during the labor dispute compared with those produced after the dispute, or compared with those from other, non-striking plants. Monthly data suggest that the production of defective tires was particularly high around the time wage concessions were demanded by Firestone in early 1994 and when large numbers of replacement workers and permanent workers worked side by side in late 1995 and early 1996.
\end{abstract}

\author{
Alan B. Krueger \\ Industrial Relations Section \\ Firestone Library \\ Princeton University \\ Princeton, NJ 08544 \\ and NBER \\ akrueger@princeton.edu
}

\author{
Alexandre Mas \\ Industrial Relations Section \\ Firestone Library \\ Princeton University \\ Princeton, NJ 08544 \\ amas@princeton.edu
}


Do workers provide more effort and due diligence if they feel they are treated better? Does the labor relations climate affect the quality of production? Economic models of fairness (e.g., Rabin, 1993 and Fehr and Gächter, 2000) suggest that workers are more cooperative and less prone to commit sabotage if they feel they are treated well and in good faith. In addition, the dependence of worker effort on pay is an essential feature of efficiency wage models. Yet a relationship between worker treatment and the quality of production has proved difficult to establish. Quality is often unobserved or hard to measure. This paper provides new evidence on the impact of labor strife on the quality of production at the plant level by examining the incidence of defective Bridgestone/Firestone (B/FS) tires.

In August 2000, Firestone and Ford jointly announced the recall of 14.4 million size P235/75R15 ATX, ATX II and Wilderness AT tires, some 6.5 million of them still on the road, mostly on Ford Explorers. ${ }^{1}$ The National Highway Traffic and Safety Administration (NHTSA) issued an advisory concerning several other sizes and models of Firestone tires in September 2000. NHTSA reported that the Firestone tires under investigation were related to 271 fatalities and more than 800 injuries. The most common source of failure of the recalled tires was tread separation; that is, a sudden detachment of the rubber tread from the steel belts, causing the tire to blow out. One of every 400 tires produced in the Decatur, IL plant in 1995 was returned under warranty because of a tread separation by $2000 .^{2}$

\footnotetext{
${ }^{1}$ The recall pertained to size P235/75R15 Firestone ATX and ATX II tires made in all Firestone plants from 1991 to 2000, and P235/75R15 Wilderness AT tires produced in the Decatur, IL plant from 1996 to 2000. On May 22, 2001 Ford announced plans to replace all Wilderness AT tires on certain Ford vehicles. In October 2001 Firestone recalled additional P235/75R15 tires and P255/70R16 Wilderness AT tires.

${ }^{2}$ This figure is based on our calculations using warranty data provided by B/FS to NHTSA, and is an underestimate of the overall incidence of tread separations because not all tires were covered by the
} 
As described in detail in the next section, three of Firestone's 11 North American tire production plants, including its Decatur, IL plant, which manufactured a large number of P235/75R15 tires, underwent a severe strike beginning in July 1994. The previous contract expired on April 1, 1994, and employees worked without a contract for three months before going on strike. In negotiations, B/FS insisted on deviating from the industry-wide pattern bargain by moving from an 8 to 12 hour shift that would rotate between days and nights, as well as cutting pay for new hires by 30 percent. Almost immediately after 4,200 workers walked out on strike, the company hired replacement workers. In May 1995, the United Rubber Workers (URW) locals representing the striking plants unconditionally offered to return to work without a contract, but B/FS had announced that it would permanently retain the replacement workers and offered only to recall the striking workers as need arose. In July 1995, the United Steelworkers, which had absorbed the United Rubber Workers union, launched a worldwide campaign to force B/FS to rehire some 1,000 strikers who remained out of work. A final contract, which included provisions to recall all strikers, was not settled until December 1996.

A unique vista into the possible effect of labor relations on product quality is possible in this instance because the recall of Firestone tires, Congressional hearings, and scores of liability lawsuits have made confidential, proprietary data publicly available. Tires are still made in large part by hand, so there is scope for human error in producing this product. In addition, because millions of tires are produced and in service each year, failure rates can be calculated for an enormous sample.

warranty program at the time of a tread separation, and because some owners may not have returned covered tires under the warranty program despite having a tread separation. 
Laboratory tests by Firestone and Ford have been unable to identify a single manufacturing or design defect that is responsible for the high incidence of defective tires. A variety of different types of defects were probably at work. Is it possible that the labor dispute affected the safety of the tires? A number of observers - Congressmen, plaintiffs' attorneys, reporters - have hypothesized that under-trained replacement workers or lax supervision during the strike contributed to the tire defects. It is also possible that discord among replacement workers, union members who crossed the picket line, and returning strikers contributed to the production defects. And workers may have been fatigued and more prone to errors because Firestone introduced a 12-hour, rotating shift to operate the plant 24 hours a day during the strike.

At least five other hypotheses have been proposed as the source of defective tires. First, B/FS executives blamed the defects in part on the design of the Ford Explorer, which they argued was prone to roll over. Second, B/FS also argued that Ford recommended that the air pressure of the tires be set at 26 pounds per square inch (PSI), while the tire manufacturer recommended 30 PSI. At lower pressures tires become hotter and are more prone to blow out. Third, others have conjectured that features of the manufacturing process in the Decatur plant increased the risk of safety defects, including a shortening of the vulcanization process (time that tires are cooked to imprint the tread) and plant conditions that may have allowed moisture to seep into the rubber linings. Fourth, some tire experts and workers have conjectured that faulty material inputs, such as outdated rubber, weakened tires manufactured in Decatur. Finally, some have claimed that the design of the tires was responsible for the high rate of tread separations.

Anecdotal evidence is available for all these explanations. In sections 3-5 we try to systematically sort through the possible reasons for the safety-related defects, focusing 
closely on whether the production of defective tires coincided with the labor dispute. We examine three different data sets, and provide five types of evidence. We focus mostly on P235/75R15 tires because they have more data available, but look at other tires as well. Almost all of the P235 tires were produced in three plants: Decatur, IL; Joliette, Canada; and Wilson, NC. For nearly three years -- from April 1994 to December 1996 -union workers at the Decatur plant were either on strike or working without a contract; tires were produced by 1,048 replacement workers, union members who crossed the picket line, management and recalled strikers in this period. The Wilson plant was nonunion, so it did not experience a strike. A Canadian union represents the Joliette plant, but labor relations there were much less contentious. Joliette had a six-month strike over fringe benefits at the end of 1995, but the plant did not hire replacement workers (which are illegal in Quebec).

The evidence that we have assembled suggests that the strike and associated labor strife in Decatur was a major contributing factor to the production of defective tires. First, descriptive analysis and count regression models using data on claims for compensation for property damage or personal injuries show significantly higher defect rates for tires manufactured in Decatur during the labor dispute (defined as 1994-96) than in Decatur at other times, or in other plants, conditional on production and other variables. Second, NHTSA data on complaints involving Firestone P235/75R15 tires indicate a similar pattern: a significantly higher incidence of complaints filed concerning tires manufactured in Decatur during the strike period than at other times, or at other plants. Third, engineering tests conducted by Firestone - which hold conditions such as speed, load, tire pressure and ambient temperature constant - indicate a higher failure rate 
for tires manufactured in Decatur during the strike compared with tires manufactured in Decatur during non-strike years or in other plants.

Fourth, we more closely examine the timing of the production of defective tires, using data on the number claims disaggregated by the month the tires were produced. This analysis finds an excess number of claims for tires produced in Decatur in the few months before the contract expired, when B/FS demanded concessions, and in the period when many replacement workers and recalled union workers worked side by side. This finding leads us to a somewhat nuanced conclusion on the role of replacement workers: it is not simply that under trained or poorly supervised replacement workers produced defective tires. Instead, the timing suggests that the concurrence of replacement workers and union members working side by side before the contract was settled, as well as labor strife in the months leading up to the strike, coincided with the production of a high number of defective tires.

Fifth, we examine other models of Firestone tires, which have not been recalled by Firestone. If labor strife contributed to the production of defective P235/75R15 tires, then one would expect the quality of other Firestone tires manufactured under the same labor relations environment to have been affected as well. Results for these tires also suggest that a higher rate of defective tires were produced in Decatur during the strike years than in Decatur before or after the strike, or in other plants.

Although these findings suggest that labor strife contributed to the problems with Bridgestone/Firestone tires, it is unclear whether one can generalize from our results to other settings because tire manufacturing may be different from other industries and because the investigation into the problems with P235 tires made our case study possible in the first place, so "selection bias" may be an issue. Our findings were not preordained, 
however, because at the start of our work we were unaware that an excess number of defective tires were produced during the dispute period in the Decatur plant, or that the precise timing would indicate a major role for union workers as opposed to replacement workers, or that there was an unusual number of problems with non-P235 tires manufactured in the Decatur plant during the dispute. Still, we would recommend that the reader exercise caution in extending our results to other settings; our paper only provides a detailed case study of one firm in one unique period of its history.

\section{Background and Industrial Relations Environment}

In 1988, the Japanese tire manufacturer Bridgestone purchased Firestone, making Bridgestone/Firestone the largest tire manufacturer in the world. Initially, labor relations went smoothly. For example, Bridgestone upheld Firestone's agreement to allow its new plant in Warren County, TN to organize by means of a card sign-up, foregoing a secret ballot. In 1991, the three-year contract negotiated between Bridgestone and the URW became the pattern for the tire industry, and the company and union established a much ballyhooed "Partnership for Involvement" program. ${ }^{3}$ When negotiations began in January 1994, however, B/FS sought to deviate from the industry-wide practice of pattern bargaining, asking for what a company negotiator called "a turnaround agreement". Since the 1940s, Firestone plants had adhered to the industry wide pattern bargain. Peter Schofield, Firestone's former Director of Labor Relations, said the January 1994 bargaining session “certainly didn't make the union happy” (Meyer, 2002; p. 337).

\footnotetext{
${ }^{3}$ The material in this paragraph draws heavily from Franklin (2001) and Meyer (2002).
} 
Bridgestone/Firestone demanded that the union move from 8-hour to 12-hour shifts that rotated between day and night, that it operate the plant seven days a week, that the pay of new hires be reduced by 30 percent (although the cut would be made up by faster seniority increases over a three-year period), that hourly workers contribute to their health care costs, that the piece rate system be moved to a plant-wide performance pay system, and that vacations be cut by two weeks for senior workers. This request for concessions came at a time of falling national unemployment and just after B/FS's first profitable year since being acquired by Bridgestone (Whitford, 1994). The URW proposed that Bridgestone/Firestone follow the master pattern agreement set with Goodyear, which called for no wage increases other than cost-of-living adjustments. ${ }^{4}$ After the contract expired on April 1, 1994, union members continued working without an agreement. On July 12, 1994, URW locals representing 4,200 workers in three of B/FS's production plants (Des Moines, Decatur, and Oklahoma City), the Akron research center, and the Noblesville air springs plant went on strike. Bridgestone almost immediately began to hire temporary replacement workers and operate the plants with managerial and supervisory workers. Replacement workers were paid 30 percent less than the union rate. ${ }^{5}$ By January 1995 , when the company converted temporary replacement workers to permanent replacement worker status, it had hired a total of 2,300 replacement workers. ${ }^{6}$

The union set up pickets outside the struck plants. In Decatur, the union posted the names of each member who crossed the picket line under the title, "Hall of Shame."

\footnotetext{
${ }^{4}$ The previous agreement at Goodyear also expired in April 1994, and the new contract was settled as soon as the old one expired.

${ }^{5}$ Franklin (2001; p. 140).

${ }^{6}$ Franklin (2001; p. 140).
} 
The list included a previous president of the local union. ${ }^{7}$ More than 300 of the 1,209 members of Local 713 in Decatur eventually crossed the picket line. By May of 1995, the Decatur plant employed 1,048 replacement workers and 371 permanent workers. ${ }^{8}$ The company initiated 12-hour, rotating shifts, and operated the plant 24 hours a day.

On May 7, 1995, members of the URW Local 713 in Decatur voted by a 2-1 margin to officially end their strike against B/FS. The other plants quickly followed suit. ${ }^{9}$ On May $22^{\text {nd }}$, the URW unconditionally offered to return to work. According to Local 713 President Roger Gates, the union offered to unconditionally end the strike as a strategy to prevent B/FS from hiring additional replacement workers and to forestall a union decertification election. ${ }^{10}$ The strike was the longest in the history of the URW; its strike fund was depleted. Bridgestone/Firestone unilaterally imposed its last offer from July 1994 , which cut wages for some job classifications by $\$ 5.34$ an hour, to about $\$ 12$ per hour, moved piece rate pay to a flat hourly rate plus plant-wide performance pay, paid new hires 30 percent less than before the strike, froze pension benefits, and required workers to contribute a portion of their health care premiums. ${ }^{11}$ The company also continued operating 12-hour shifts.

Although the strike officially ended in May 1995, the labor dispute continued. The company notified the union that it intended to permanently retain the replacement workers and that it would "advise the URW of the number of employees for whom we

\footnotetext{
${ }^{7}$ Franklin (2001; p. 127).

${ }^{8}$ Statistics included in a letter submitted by Theodore Hester on behalf of B/FS, contained in House Committee on Commerce (2001) documents, p. 107.

${ }^{9}$ In January 1995 the local representing the research facility in Akron had voted to end the strike.

${ }^{10}$ U.S. Department of Labor (1996; p. 2).

${ }^{11}$ U.S. Department of Labor (1996; p. 2).
} 
have work."12 In July 1995, the financially bankrupt URW voted to merge into the United Steel Workers of America (USWA). The URW ceased to exist. The USWA made the rehiring of all striking workers a priority for future negotiations, but B/FS and USWA did not reach a new agreement until December 1996. On July 18, 1995 the USWA announced a worldwide boycott of Bridgestone/Firestone and Sears Roebuck \& Co., its largest domestic retailer. The union said it initiated the boycott because the company insisted on retaining replacement workers instead of recalling some 2,000 strikers who were willing to return to work. ${ }^{13}$ The USWA broke off contract talks in January 1996 because B/FS would not agree to a system of pattern bargaining.

A final settlement, which included an agreement to recall all strikers, was ratified in December 1996. The new contract gave an across-the-board wage increase of 35 cents compared to the 1994 levels, a $\$ 750$ bonus, and restored pension benefits. Hourly wages were about $\$ 1$ below the rate at Goodyear. ${ }^{14}$ A 12-hour shift remained in place, but it no longer rotated between day and night for the same worker.

Most strikers had been recalled prior to the final contract agreement. ${ }^{15}$ By early November 1996, all but 40 strikers were recalled. Bridgestone/Firestone increased the operation of its plants to 24 hours a day, seven days a week during the strike, so total employment increased. Because B/FS gradually recalled strikers after the union unconditionally agreed to return to work, replacement workers and returning strikers

\footnotetext{
${ }^{12}$ Statement of B/FS spokesperson Trevor Hoskins.

${ }^{13}$ U.S. Department of Labor (1996; p. 3). Among other activities, the USWA staged an anti-Firestone protest at the Indianapolis 500.

${ }^{14}$ Sabath (1997).

15 John Lampe, B/FS's Executive Vice President, testified that "by 1996, over half of our work force in the Decatur plant was unionized workers that had gone on strike and come back, and less than half were then replacement or temporary workers" (House Committee on Commerce, 2000; p. 1391).
} 
worked side by side for several months before a new contract was reached. A USWA document described conditions during this period as follows: ${ }^{16}$

Working conditions for the returning strikers were brutal. Forced to work alongside scabs who had taken their jobs and unprotected by a contract, the strikers were assigned to the hardest jobs on the worst machines, rather than the jobs the y had held for 10, 20 and even 30 years. The company supervisors had a field day harassing, intimidating and firing union members for the smallest infractions.

The antagonism between the union and those who crossed the picket line is also illustrated by the fact that the union imposed a $\$ 4,500$ fine on anyone who crossed the picket line who wanted to rejoin the union. Only one Decatur worker, who crossed the picket line in the last week of the strike, paid the fine and was taken back by the union. ${ }^{17}$ Greenhouse (1996) observed, "Organized labor made the dispute one of its crusades largely because it involved one of the largest uses of permanent replacement workers in the nation's history."18

\section{Tire Production}

Column 1 of Table 1 reports the number of ATX, ATX II and Wilderness sizeP235/75R15 tires produced in each of the six Firestone plants that manufactured such tires from 1991 to 2000. (Henceforth, we use P235 to refer to size P235/75R15 tires and ATX to refer to both ATX and ATX II models.) The Decatur, Joliette and Wilson plants produced the vast majority of these tires. Wilderness tires were not produced until 1996.

\footnotetext{
${ }^{16}$ United Steel Workers, “One Day Longer: The road to victory at Bridgestone/Firestone," undated, available from http://www.uswa.org/news/bridgestone.html.

${ }^{17}$ Franklin (2001; p. 283).

18 There are many other notable examples where labor strife has arisen during strikes in which replacement workers were hired. Examples include the Hormel strike of 1985-1986 in Austin, MN (Green, 1990), the Iowa Beef Packers strike of 1987 in Dakota City, IA (Craypo, 1994) the Phelps Dodge Corporation strike of 1983 in Phelps Dodge, AZ (Rosenblum, 1995), and the International Paper Strike of 1988 in Jay, ME, which coincided with toxic gas leaks leading to the evacuation of the town (Bierecree, 1991).
} 
A smaller number of ATX tires continued to be produced after Wilderness tires were introduced. The last column summarizes the labor relations situation in the 1990s.

Tire manufacturing remains a highly complex, labor-intensive task. According to Firestone's former CEO, Masatoshi Ono, "A typical tire can have more than 26 components, 14 different rubber compounds and require 29 separate steps to manufacture."19 The Decatur plant is Firestone's oldest manufacturing facility. The plant was originally used by Caterpillar to build large engines for the U.S. military during World War II. It was next used as a U.S. Army Signal Depot until 1961. In 1962 Firestone purchased the 160 -acre site and converted it to produce tires. Local 713 of the URW immediately organized it. Franklin (2001; p. 117) describes the plant as, "dark, brooding, and smoky in places, a noisy monument to the almost unchanging way most tires are still made: with much reaching and lifting and cutting, a lot of human muscle power, and an endless demand for unflinching robot-like concentration.” Particularly in the Decatur plant, tire production was not automated. For example, workers had much discretion over the amount of effort exerted to wrap the steel belts, the condition of the rubber used to produce the tread and sidewall, and the implementation of the vulcanization process.

There is much anecdotal evidence that replacement workers were less skilled tire makers, and perhaps more prone to build defective tires. According to William Newton, a retired tire builder from the Decatur, "It takes two years to become a good tire builder." When Mr. Newton returned to work after the strike, he said he "saw a lot of people who

\footnotetext{
${ }^{19}$ Quoted in Adams (2000).
} 
didn't know how to build tires. $" 20$ Joe Roundtree, another retired worker from Decatur, reportedly testified in a civil case that he doubted the ability of replacement workers to match the quality of experienced union workers and that he thought moving to 12-hour shifts compromised product quality. ${ }^{21}$

Other employees have testified that they were ordered to remove blisters from tire sidewalls by piercing them with an awl, a small, handheld pointed instrument, and that production pressures during the labor dispute impaired quality. "I protested it, but I done it," Jan S. Wagoner said. "I didn't like sticking an awl all the way through the sidewall of a tire."22 The Decatur plant manager, Harry McMillan, testified that the plant "was not producing the volume of tires it was expected to produce [during the dispute], and waste and scrap levels were higher than the company expected them to be."23 Tires are scrapped if a defect is detected. "They preached quality," Lonnie Dart, a retired Decatur worker testified, "but if you didn't make the numbers, you was in trouble." ${ }^{24}$ According to one news account, production quotas made thorough inspections nearly impossible (Barboza, 2000).

\section{Tire Safety}

Tires are more likely to fail if they run at higher speeds, at higher temperatures, or carry heavier loads. Older tires are also more likely to suffer a tread separation. A large majority of tread separations occurred in the Southwestern part of the United States, almost certainly because of the higher average temperature there. We are not aware of

\footnotetext{
${ }^{20}$ Quoted in Barboza (2000).

${ }^{21}$ Fogarty (2000).

${ }^{22}$ Skertic (2000).

${ }^{23}$ Quoted in Pinkerton (2001a).

${ }^{24}$ Skertic (2000).
} 
any evidence indicating a change in the regional distribution of Firestone tires produced in different plants, but the location of tires that are installed as original equipment, as opposed to replacement tires, is determined by the auto manufacturer.

One possibly relevant development was that Ford began producing Explorers at a new plant that opened in St. Louis in 1995, and many of these vehicles were sent to dealers in the Southwest. The other Explorer plant was in Louisville, Kentucky. Firestone's Decatur plant likely supplied tires to both plants, because of its proximity. There are several reasons why we doubt that the temporal pattern of defective tires originating from Decatur that we document below was caused by a change in distribution to warmer states during the dispute, however. First, the St. Louis plant began producing in 1995, but there was already an excess number of defective tires produced in Decatur in early 1994. Second, our results are robust if we limit the analysis to replacement tires, which are unaffected by the new Ford plant. Third, the excess number of defects from Decatur abated after 1996, while the St. Louis plant continued to operate. Fourth, and perhaps most importantly, engineering tests that hold constant temperature and other environmental factors point in the same direction as the field data.

Historically, Firestone has monitored tire safety by running product tests, studying warranty adjustment information, and analyzing failed tires that were returned from the field. Another source of information is claims paid for property damages and personal injuries. According to Congressional testimony, the company did not closely monitor these data for safety purposes until July 2000, in a joint effort with Ford. ${ }^{25}$

\footnotetext{
${ }^{25}$ House Committee on Commerce (2001; p. 137). In a deposition for a civil suit in Texas, Allen Rauner, a Ford engineer, testified that he requested claims data in 1999 from Firestone, but was told the company did not have such data (Pinkerton, 2001b).
} 
The third column of Table 1 reports the number of claims for property damages or personal injuries involving Firestone ATX tires. It is clear that the Decatur plant has a much higher rate of claims per million tires produced. A key question is: was the claims rate elevated for tires made during the labor dispute.

\section{Firestone Claims and NHTSA Complaints Data Sets and Descriptive Analysis}

We obtained Firestone's internal claims data from NHTSA. These data consist of a brief description of claims filed before 2000 for property damage or personal injuries stemming from tire failures. About 70 percent of the claims involved problems related to tread separations. The data we analyze includes claims concerning 2,597 P235 tires produced between 1991 and 1999. The data set includes micro data on tire model and size, date of failure, and the 10-digit Department of Transportation (DOT) tire code, from which plant and week of production can be inferred.

We use these data to construct a cell-level data set, where the cell is a production year by age by plant. We also have added information for each cell on the number of P235 tires produced (by model), the share of tires that were used as original equipment, and the share of tires that are ATX model, which were all provided by Safety Forum, a non-profit organization that works with trial attorneys involved in lawsuits against Firestone and Ford.

The second set of data on failures was collected by NHTSA. These data are described in detail in the Data Appendix. Briefly, NHTSA recorded information reported by consumers, police authorities, insurance companies and other organizations on Firestone tires that failed. The NHTSA data also include information on the tire model and size, date of failure, and DOT tire code. We use these data to construct a cell-level 
data set on the number of complaints by year of production, plant and age. One advantage of the NHTSA data set is that it indicates whether the tire failure resulted in a fatality or injury, allowing us to calculate failure rates depending on the severity of the incident. Another advantage is that we can analyze data on P235 and non-P235 tires. And unlike the claims data, the complaints data indicate whether the tire was installed as original equipment or as a replacement tire.

There are three major shortcomings with the NHTSA complaints data, however. First, the records contain many missing values for the variables of interest. Of 5,189 reported complaints (on all tire sizes), only 1,076 have complete data, 3,524 have partial data, and 586 are missing data on the production year, plant and calendar year of failure of the tire. Second, many complaints were filed after the recall was announced, and may involve routine use-related failures, such as running over a nail. Third, there is no financial incentive to report complaints to NHTSA, as opposed to claims data, so underreporting is probably common. We limited the data to complaints filed before the August 2000 recall to avoid an avalanche of frivolous complaints, or complaints that were sparked because the recall singled out Wilderness tires made in Decatur. Before the recall, it was not publicly known that Decatur tires might have a higher defect rate.

As explained in detail in the Data Appendix, to handle the missing values we multiply imputed missing data using the conditional distribution for the available data using a technique based on Rubin (1987). If, say, a randomly chosen half of all complaints had missing data, we could just double the number of complaints with complete data. But this would not make use of the partially reported data, and we could probably do better filling in the missing data by conditioning on the information that we 
do have. For example, if a tire's age was missing, we randomly assigned the age from the set of tires with the same year of production and vehicle miles.

Although it is possible to utilize a more sophisticated technique to impute missing values, given the strong likelihood that data are randomly missing (e.g., a tire was so badly damaged that the DOT code was not visible) we implemented a simple, transparent hot-decking technique that relied on a priori expectations of which variables contain information on the missing values. We created 10 micro complaints data sets imputing missing values in this way, and then aggregated each micro data set into plant-by-year-ofproduction-by-age cells. We report summary statistics for the average of the 10 cell-level data sets. The advantage of proceeding in this way (as opposed to assigning conditional expected values to missing data) is that the standard errors that we compute take into account sampling variability introduced by the imputation method (see Data Appendix). The assumption that is required for the consistency of the estimates using both imputed and non-imputed data is that the missing data are missing at random conditional on the variables used in the imputation. It is reassuring to note that none of our conclusions is qualitatively altered if we use only the non- missing observations. ${ }^{26}$

Although both the claims and complaints data sets have limitations, they complement each other and have the virtue of being independently collected. For example, while the claims data are more complete and claimants have a financial incentive to file a claim, they lack information on the severity of resulting injuries. Moreover, there is no industry-wide standard definition of a claim, so the claims data rely on Firestone's interpretation and recording of claims.

\footnotetext{
${ }^{26}$ Estimates using the sample of complaints without imputed data are available on request.
} 


\section{Descriptive Analysis}

Figure 1 reports the cumulative number of claims against Bridgestone/Firestone per million ATX tires produced by the year the tires were produced and the age of the tires. The left panel displays data for the Decatur plant and the right panel for Joliette and Wilson, the two other main producers. ${ }^{27}$ The three years of the labor dispute -1994 , 1995, and 1996 - stand out in the figure for Decatur. Four years after production, tires that were made in Decatur during the labor dispute were at least 15 times more likely to have resulted in a claim than were tires manufactured in other plants. Such a large discrepancy in failure rates is not evident for other production years, although the claims rate was about double for Decatur tires than other tires for the 1993 production year.

Figures 2 and 3 report similar figures using the complaints data for ATX and Wilderness size-P235 tires combined. Figure 2 uses only the subsample with complete data for year, plant and age, while Figure 3 uses the average of 10 data sets with allocations for missing data, as described previously. The number of complaints is about half as large as the number of claims, even after imputations are made for missing data. Nonetheless, both figures tell a similar story, and a story similar to the claims data: tires produced during the labor dispute (1994-96) at the Decatur plant have a much higher failure rate than those produced at Joliette or Wilson, although before and after the dispute period the rate of complaints is similar for tires manufactured in Decatur and in the other plants.

\footnotetext{
${ }^{27}$ Ford submitted a similar graph in Congressional testimony, although it pertained just to tread separations and combined all plants other than Decatur (see House Committee on Commerce, 2001; p. 153).
} 
Figure 4 displays cumulative incidence rates for cases in the NHTSA database involving at least one fatality. ${ }^{28}$ That is, we report the cumulative number of recorded tire failures linked to a fatality per million tires produced, by year of production, plant and age of tire. This sample was selected because fatalities are unlikely to be under counted in the NHTSA data and because records for cases involving fatalities were less likely to have missing data. Even with a small number of counts, these graphs convey a similar message: a higher rate of fatal accidents involving tires produced in Decatur during the labor dispute than tires produced in other plants, or tires produced in Decatur during a more tranquil period of labor relations. To put the numbers in perspective, note that before the recall tires made in Decatur during the labor dispute had a fatal accident rate of 10 to 30 per million tires produced. As a benchmark, we note that the risk of death from parachuting is estimated at 13 per million jumps (Poytner, 1992). ${ }^{29}$

\section{Count Data Models}

To model tire failures conditional on other variables, we estimate a series of count data regression models. Specifically, we model $y_{\mathrm{ijt}}$, the number of claims (or complaints) for tires produced in plant $\mathrm{i}$ in year $\mathrm{j}$ that failed in calendar year $\mathrm{t}$ as:

$$
\mathrm{E}\left(y_{\mathrm{ijt}} \mid \boldsymbol{x}_{\mathrm{ijt}}\right)=\exp \left(\boldsymbol{x}_{\mathrm{ijt}}^{\prime} \$\right)
$$

\footnotetext{
${ }^{28}$ The figure uses imputed data for missing values. The results are quite similar if records with incomplete data are eliminated.

${ }^{29}$ Because tires are driven on frequently over several years, these statistics admittedly compare apples and oranges to dramatize the risk from tire failure. A common but still unsatisfactory alternative is to put both risks per mile traveled. One way to put the figures reported in the text in comparable context, however, is to note that the risk of a fatal tire blowout is reduced by changing one's tires, and each car has four tires with more or less mutually exclusive risks, so the reduction in risk for a driver from replacing P235 tires manufactured during the labor dispute surely exceeded the risk reduction from refraining from one parachute jump.
} 
where the $\boldsymbol{x}$-vector of explanatory variables includes the logarithm of tires produced in plant $\mathrm{i}$ in year $\mathrm{j}$, a dummy variable indicating tires manufactured in Decatur, a dummy indicating tires manufactured during the labor dispute (defined as 1994-96), an interaction between the Decatur dummy and labor dispute dummy, a quadratic in tire age, and possibly other variables such as the fraction of tires in the cell that were installed as original equipment on new vehicles. The vector of parameters is denoted $\$$.

The "law of rare events" holds that the total number of events of some kind occurring in a time interval will approximately follow a Poisson distribution if a single event may occur in any of a large number of trials, but the probability of the event occurring in any one trial is small. Tire failures would seem a natural to model as a Poisson process because they are rare events and there are a large number of trials, with hundreds of thousands of cars driving on tires made in the same plant and year. A testable restriction of the Poisson model is that the conditional mean, $\mathrm{E}\left(y_{\mathrm{ijt}} \mid \boldsymbol{x}_{\mathrm{ijt}}\right)$, equals the conditional variance, $\operatorname{Var}\left(y_{\mathrm{ijt}} \mid \boldsymbol{x}_{\mathrm{ijt}}\right)$. Even if this restriction does not hold, however, Poisson maximum likelihood estimates of \$ are still consistent if equation (1) is a correct specification, although the standard errors are inconsistent.

A common feature of count data - and one that we find in our tire failure data - is that the conditional variance exceeds the conditional mean. As a consequence, to avoid understating the standard errors we compute robust standard errors that are consistent in the presence of over dispersion. ${ }^{30}$ Specifically, we allow:

$$
\operatorname{Var}\left(y_{i} \mid \mathbf{x}_{\mathbf{i}}\right)=\alpha \exp \left(\mathbf{x}_{\mathbf{i}}{ }^{\prime} \beta\right), \quad \alpha>1,
$$

\footnotetext{
${ }^{30}$ See Cameron and Trivedi (1998; p. 63-65) on robust Poisson.
} 
where " is an over dispersion parameter. The robust standard errors thus equal the usual Poisson standard errors multiplied by $\sqrt{\alpha}$. We estimate $\alpha$ by:

$$
\hat{\alpha}=(n-k)^{-1} \sum_{i=1}^{n}\left(y_{i}-\hat{y}_{i}\right)^{2} / \hat{y}_{i}
$$

In addition, we present estimates of Negative Binomial models for our first set of specifications. The Negative Binomial model does not impose the restriction that the mean equal the variance, and are also consistent if equation (1) holds.

Table 2 reports means of the two cell-level data sets we use to estimate count models. The first two columns present summary statistics for the Firestone claims data set and the next two for the NHTSA complaints data set. In both data sets, we have combined data on ATX and Wilderness tires. The dependent variable $\left(y_{\mathrm{ijt}}\right)$, shown in the first row, is the total number of failures in either ATX or Wilderness P235 tires in a particular plant-by-year-of-production-by-calendar-year. Cells in the claims and complaints data sets are for three plants (Decatur, Joliette, and Wilson), by nine production years (1991-99), and nine calendar years (1991-99). The first and third columns present unweighted means, and the second and fourth columns use as weights the number of claims or complaints in the cell. Thus, columns 2 and 4 provide some information on the characteristics of tires that failed.

Complaints are only about half as common per cell as claims. This finding probably reflects under reporting of complaints in the NHTSA data. Nevertheless, the characteristics of the failed tires are quite similar. In both data sets, for example, more than 90 percent of the failed tires are ATX models, reflecting the fact that ATX tires have a higher failure rate and are older (and therefore more likely to fail) in these samples. The average failed tire is around 3.5 years old at the time of the incident. About half of 
the failed P235 tires were produced in Decatur during the period of the labor dispute (1994-96); by comparison, only 9 percent of all P235 tires manufactured from 1991 to 1999 were produced in Decatur in this period.

Table 3 presents Poisson models for the Firestone claims data (columns 1-3) and for the NHTSA complaints data (columns 4-6). The first model conditions on log production and includes dummy variables indicating tires made in Decatur, made during the labor dispute in any plant, and the interaction between the two. The second model also conditions for the age and age-squared of the tire. The third model adds controls for the proportion of tires produced in the plant that year that are ATX model and the fraction of tires that were installed as original equipment.

In all the models, tires produced in Decatur during the labor dispute are found to have a statistically significantly higher rate of claims or complaints. First consider the results for claims. In column (3), for example, the Decatur-dispute interaction has a coefficient of 1.48 , with a t-ratio of 2.79 . This coefficient is a "difference-in-differences" estimate in that it measures the difference in claims between the dispute period and nondispute period in Decatur less the difference over the corresponding time periods in the other plants, conditional on the other variables. To interpret the magnitude of the interaction effect, note that $\exp (1.48)=4.39$, which implies that the incidence of claims is 339 percent higher for tires produced in Decatur during the labor dispute, other things held constant. The Decatur main effect is statistically insignificant in column (3), suggesting that, before and after the dispute, chance cannot be ruled out as the explanation for the difference in claims rates between tires manufactured in Decatur and those manufactured in Joliette and Wilson. Furthermore, the dispute period dummy is 
insignificant, suggesting that tires from Joliette and Wilson did not result in an increase in claims if they were manufactured during the labor dispute.

The coefficient on the log production variable can be interpreted as a "defect-scale" elasticity. Interestingly, in the models in columns 2 and 3, the number of claims rises more than in proportion with the number of tires produced, suggesting that failures exhibit "increasing returns to scale," perhaps because of (accelerating) fatigue in the production process. But in column (3) the coefficient is statistically indistinguishable from 1.0, so constant returns to scale cannot be rejected.

Surprisingly, the proportion of tires in a cell that are ATX models has a small and statistically insignificant, though positive, effect on the incidence of claims. The proportion of tires installed as original equipment has a negative coefficient, which is also statistically insignificant.

Insofar as the labor dispute is concerned, the results for complaints are similar to those for claims. The Decatur-dispute interaction is highly statistically significant, with a t-ratio of 4.89 in column (6). The model in column (6) indicates that tires made in Decatur during the labor dispute were associated with $\exp (1.71+.20)=6.75$ times more complaints than tires made in Decatur before or after the dispute. Similarly, tires manufactured in Decatur during the strike were associated with $\exp (1.71+.20-.15)=5.81$ times more complaints than tires manufactured in Wilson or Joliette in non-dispute years. The number of complaints concerning tires produced during the dispute in Joliette and Wilson is insignificantly higher than that for tires produced there in other years. And it is worth noting that for both claims and complaints we cannot reject that the plant main effect and dispute-interaction are equal for Wilson and Joliette if we estimate a model that allows their coefficients to differ. 
As with the claims, the production variable has close to a unit elasticity in the complaints models in column (5) and (6). The coefficient on proportion new equipment is negative in the complaints equation, and statistically significant in this case.

For both dependent variables, the coefficients on the age variables display an inverted-U shaped pattern, with the number of failures peaking when tires are around 5 years old. Note that we have made no adjustment to production for tires that are no longer in service. Older tires are more likely to be removed from the road, so the age variables in part reflect obsolescence. We could adjust production by assuming some depreciation rate each year. If we include unrestricted age dummies, however, they would completely absorb any (cross-plant) age-specific obsolescence rate because of the logarithmic specification of production. When we included unrestricted age dummies the coefficients on production and the Decatur and labor dispute dummies were hardly changed, and the pattern of age effects indicated that the quadratic specification of age fit the data reasonably well. For example, if the model in column (3) of Table 3 is estimated with unrestricted age dummies, the coefficient on production is 1.28 (versus 1.27 ) and the coefficient on the Decatur-dispute interaction is 1.45 (versus 1.48). Because the results are so similar if age dummies are included, we have used the more parsimonious quadratic specification.

If we limit the sample of complaints to those involving replacement tires - which are not subject to the regional distribution decisions of the auto manufacturer - the results are very similar. For example, the coefficient on the Decatur-dispute interaction in the model in column (5) of Table 3 rises from 1.73 to 2.30 (with a t-ratio of 4.6) if the analysis is limited to spare tires. The other coefficients are also qualitatively similar. 
This finding suggests that possible changes in Ford's distribution practices are unlikely to account for the results in Table 3 .

As mentioned previously, the Poisson models impose the constraint $\operatorname{Var}[y \mid x]=$ $\mathrm{E}[y \mid \boldsymbol{x}]=\exp \left(\boldsymbol{x}^{\prime} \$\right)$. A generalization of the Poisson, the Negative Binomial II model, specifies the conditional variance as $\operatorname{Var}[y \mid x]=(1+8) \exp \left(x^{\prime} \$\right)$ while maintaining equation (1). If $8=0$ the Negative Binomial is equivalent to a Poisson. A common test for over dispersion is a likelihood ratio test of whether $8>0$. Table 4 presents MLE estimates of Negative Binomial regression models corresponding to those in Table 3. Both the claims and complaints data exhibit over dispersion. This causes the standard errors on many of the coefficients to roughly double in the Negative Binomial model compared to a conventional Poisson model. The parameter estimates are fairly similar in the Negative Binomial regressions, however, as one would expect because both models are consistent if equation (1) holds.

In Table 5 we present additional Poisson models where the unit of observation is disaggregated into finer cells, delineated by ATX or Wilderness tires as well as year of production, plant, and calendar year of failure. We pool the ATX and Wilderness cells together in the sample, and include a dummy variable indicating whether the cell pertains to ATX or Wilderness tires. These models provide a more precise assessment of whether ATX tires have a higher failure rate than Wilderness tires. Indeed, the results for both claims and complaints indicate a substantially higher failure rate for ATX tires, other things equal. The other results are fairly similar to those for the more aggregate cells in Tables 3 and 4. 


\section{Incidents with Fatal and Nonfatal Injuries; NHTSA Data}

Table 6 presents estimates of Poisson models using the NHTSA complaints database, where we provide separate estimates for the number of cases involving at least one fatal accident, number of cases involving a non-fatal injury, and number of cases without a reported injury. The unit of observation is a cell defined by plant-by-year-byage, as in Tables 3 and 4 . Because we are less concerned about reporting biases in cases involving injuries or fatalities, we use the full reporting period to calculate counts in this Table. We continue to limit the sample to tires that failed in 1999 or earlier, however. For comparison, the Appendix Table A3 reports the corresponding results for the unallocated data.

Interestingly, the coefficient on the Decatur-dispute-period interaction is positive and statistically significant -- and of roughly equal magnitude -- in all of the models. Likewise, the Decatur and dispute period main effects are statistically insignificant in all of the models. To estimate the excess number of fatal incidents involving tires manufactured in Decatur during the labor dispute, denoted ), we calculated

$$
)=E_{\mathrm{ijt}}\left\{\operatorname { e x p } \left(\boldsymbol{x}_{\mathrm{ijt}}^{\prime} \$+\mathrm{S}_{\mathrm{j}}{ }^{\prime \prime}+\mathrm{D}_{\mathrm{i}}\left(+\mathrm{S}_{\mathrm{j}}{ }^{*} \mathrm{D}_{\mathrm{ij}}{ }^{*}\right)-\exp \left(\boldsymbol{x}_{\mathrm{ijt}}^{\prime} \$+\mathrm{S}_{\mathrm{j}}{ }^{\prime \prime}+\mathrm{D}_{\mathrm{i}}()\right\},\right.\right.
$$

where $\boldsymbol{x}_{\mathrm{ijt}}^{\prime}$ is a vector of explanatory variables such as log production and proportion original equipment, $S_{\mathrm{j}}$ is a dummy variable indicating production during the dispute period (1994-96), $D_{i}$ is a dummy variable indicating production in Decatur, and $S_{j} * D_{i j}$ is the Decatur-dispute-period interaction ${ }^{31}$ In our hypothetical calculation, we set the Decatur-dispute interaction to zero, but otherwise keep production and the other variables the same. The results suggest that 35.2, or 53 percent, of the 67 fatal accidents linked to 
P235 tires were due to the excess number occurring on tires manufactured in Decatur during the labor dispute. The number of fatalities is higher because fatal accidents had 1.30 victims, on average. Thus, these results suggest that about 46 lives were lost because of the excessive number of defects occurring in P235 tires manufactured in the Decatur plant during the labor dispute.

Using the model in column (2) we can also predict the number of fatalities that were avoided because of the recall of all P235 Firestone tires. Specifically, we predicted the number of fatal accidents that would occur over the period 2000-2004 by:

$$
E_{i j q}\left\{\operatorname { e x p } \left(x_{i j}^{\prime} \$+S_{j}^{\prime \prime}+D_{i}\left(+S^{*} D_{i j}{ }^{*}+\left(A j_{0}+q\right) \sigma_{1}+\left(A j_{0}+q\right)^{2} \sigma_{2}\right\} \text { for } q=1, \ldots, 5\right.\right. \text {, }
$$

where $A_{0}$ is tire age in 1999 and $\sigma_{1}$ and $\sigma_{2}$ are the coefficients on age and age squared in the Poisson model. This calculation gives an estimate that 191.4 additional fatal accidents would have occurred on the recalled P235 tires over five years. ${ }^{32}$ Using the assumption of 1.30 deaths per fatal accident, these results suggest that 249 deaths were avoided as a result of the recall.

\section{Engineering Tests}

Firestone performs "advanced aging" tests on tires that are selected off the production line. These stress tests are designed to detect production defects before tires are in the field, and are also required for certain tire ratings. We obtained data on 106 high-speed stress tests Firestone performed on size-P235 tires, and two identical tests on

\footnotetext{
${ }^{31}$ Notice that equation (2) also equals $\mathrm{E}_{\mathrm{ijt}} y_{\mathrm{ijt}}-\mathrm{E}_{\mathrm{ijt}} \exp \left(\boldsymbol{x}_{\mathrm{ijt}}^{\prime} \$+\mathrm{S}_{\mathrm{j}}{ }^{\prime}+\mathrm{D}_{\mathrm{i}}()\right.$ because the exponential of the fitted Poisson values replicate the total count.

${ }^{32}$ Of course, it is possible that the replacement tires could also contribute to fatalities. We have no way of quantifying this effect, and suspect that it is small in any event.
} 
size P255 tires, that Firestone submitted to Congress. ${ }^{33}$ The high-speed stress test is used by tire manufacturers to obtain a Society of Automotive Engineers "S" speed rating. The test data pertain to tires produced from 1989 to 1998, although most of the data are from 1995-98, and there are only two tests available for Decatur prior to 1995, both conducted in 1990. Three of the 108 tests were either missing variables or unreadable and were therefore dropped from the analysis.

According to the protocols, the high-speed test is conducted by over inflating a tire to $38 \mathrm{PSI}$ and running it on a lab machine at specified (accelerating) speeds for prescribed lengths of time, at 100 degrees Fahrenheit (plus or minus 5 degrees) with a load of 80 percent of the maximum load stamped on the tire sidewall. For the first five minutes, the tire is run at 50 miles per hour (MPH), then the speed increases to $75 \mathrm{MPH}$ for the next five minutes, then to $87 \mathrm{MPH}$ for 10 minutes, then to $93 \mathrm{MPH}$ for 10 minutes, and thereafter the speed increases in increments of $6 \mathrm{MPH}$ after each 10 minute period. The tire undergoes this test until it bursts. The most common type of failure was a tread separation. To receive an "S" speed rating the tire must exceed $112 \mathrm{MPH}$ for 10 minutes before breaking.

The advantage of analyzing these test results is that they hold many factors constant, including the load, temperature, tire pressure, speed, and driving conditions. A disadvantage of this (and other) engineering tests is that it is unclear whether failures caused by the extreme conditions in laboratory settings can be extrapolated to everyday, normal use; the types of conditions (e.g., driving speeds) encountered in practice are

\footnotetext{
${ }^{33}$ Firestone refers to these as "Indoor Test U1". It is possible that more than 108 test results were submitted to the Congressional record, but we could only obtain 108 results from the information the committee made publicly available. Results are robust if we exclude the two tests on P255 tires.
} 
different. Nevertheless, the laboratory tests provide another check on the quality of the tires produced during the labor dispute vis-à-vis other tires.

Figure 5 presents box plots for the high-speed test results. The outcome measure used to summarize test performance is distance traveled before the tire developed a problem, as this reflects both the amount of time the tire ran and its speed. The figure indicates that tires made in Decatur during the labor dispute had lower performance on the high-speed stress test than did tires made in Decatur after the labor dispute, or tires made in Joliette or Wilson either during or after the dispute. The median tire produced in Decatur during the dispute traveled less distance before bursting than the tire ranked at the bottom $25^{\text {th }}$ percentile from the Decatur plant after the dispute or the other plants either during or after the dispute. Indeed, the tire that performed at the top $75^{\text {th }}$ percentile from Decatur during the dispute performed about as well as the $25^{\text {th }}$ percentile tire produced at other plants at the same time. Also, tires produced in Decatur during the dispute have a positively skewed distribution, while the other tires are more symmetric, which tends to exaggerate the performance of Decatur tires in least squares compared to median regression models.

Table 7 presents regression estimates where the dependent variable is the number of miles traveled on the stress test before failing, and the key explanatory variables are a Decatur dummy, dispute period dummy, Decatur-dispute-period interaction. We also control for pre-production model tires; for example, the Wilderness tire was a preproduction tire before it was marketed in 1996. Although one could argue that the preproduction tires should be excluded because they have a different design, they do provide an indication of the skill and care of the employees who built the tires at the various plants. We vary the years covered by the sample, as well as present results in the last two 
columns excluding the pre-production tires. In all cases, however, the results are similar to the box plots: tires made in Decatur did not perform as well on the stress tests as tires produced in Decatur after the dispute or tires produced in the other plants. For example, in column (3) the Decatur-dispute interaction has a coefficient of -17 miles, with a t-ratio of 3.18. Interestingly, these tires all passed the standard for an "S" speed rating, so one could reasonably question whether the standard is set at an appropriately stringent level.

\section{Precise Timing}

The NHTSA complaints data set can be used to determine the particular week in which tires that tires that resulted in a claim were produced. Although we do not have weekly production figures, we can examine whether there was an excess number of complaints generated by tires around key dates, such as when replacement workers were hired. In addition, we can make a crude adjustment for scale by interpolating annual production figures. Because the data are noisy, we examine the month the tires were produced instead of the week, but the weekly data suggest the same patterns.

Figure 6 displays the number of complaints concerning tires produced each month in Decatur. Figure 7 makes an attempt to scale complaints by monthly production; the procedure for estimating monthly production is described in the Data Appendix. The figure displays the number of complaints relative to estimated monthly production (in millions) as well as our best estimate of the number of replacement workers and permanent workers working in the Decatur plant each month. Interestingly, there was a spike in the number of tires that generated complaints in the first half of 1994, around the time when concessions were demanded and the old contract expired. Tires produced early in the strike were cited in a relatively small number of complaints, even when we 
scale by production. Continuing through early 1995, when a large number of replacement workers were building tires, the number of complaints remained relatively low. It was not until the end of 1995, when large numbers of replacement workers and returning strikers worked side by side, that the complaints rate reached its highest level. ${ }^{34}$ Complaints remained high for tires made through the first half of 1996.

For Figure 8 we constructed monthly production estimates for Joliette and Wilson tires combined, and then subtracted their monthly complaints rate from the Decatur rate to net out any temporal company-wide effects that may have existed. Figure 8 displays the difference in the complaints rate by month of production between the Decatur plant and Joliette and Wilson plants. This figure displays a similar pattern to that in Figure 7.

The monthly complaints data are somewhat noisy and sparse, and possibly affected by retrospective reporting biases. One reason we have confidence that the pattern displayed in Figures 6- 8 is not spurious, however, is that the claims data by production month show a strikingly similar pattern: an excess number of complaints in the first half of 1994 and an even larger peak in the second quarter of 1996. Figure 9, for example, displays the claims rate by month, for the Decatur plant minus the Joliette and Wilson plants.

These results suggest that faulty workmanship by novice replacement workers is not the sole source of problem tires. A more complicated dynamic is required to explain the timing of the production of defective tires. It appears likely to us that something about

\footnotetext{
${ }^{34}$ Roger Gates, former president of the URW local in Decatur, has argued that not until December 1996, when a new contract was settled, were most strikers back at work, so there was no period of time when a significant number of returning strikers worked with replacement workers (Ginsbach, 2002). This claim, however, is at odds with press releases from the AFL-CIO, which report that of the 4,200 Firestone workers who went on strike company-wide, all but 700 to 800 had been recalled by March 1996, and all but 150 had been recalled by October 1996 (see Parks, 1996a,b).
} 
the chemistry between the replacement workers and recalled strikers, or the cumulative impact of labor strife in general, created the conditions that led to the production of many defective tires. Frictions among production workers, supervisors and inspectors engendered by the strike and request for labor concessions might also have played a role. It is also possible that the Decatur plant became less vigilant at monitoring and scrapping defective tires in the second half of 1995 , which may have contributed to the dissemination of faulty tires. The fact that a multitude of different types of defects appear to have been responsible for the tire problems is consistent with our interpretation that the human element was important.

\section{Other Tire Models and Sizes}

If labor strife and ill will among replacement workers, recalled strikers and management contributed to the production of defective P235/75R15 tires, then one would expect these factors to have compromised the quality of other Firestone tires as well. The NHTSA database includes complaints concerning non-P235 tires covered by their EA00023 investigation. These data are probably not as complete as the P235 sample, but nonetheless provide information as to whether the number of complaints for other tires produced during the labor dispute was elevated. ${ }^{35}$

Table 8 presents estimates of Poisson regression models where the dependent variable is the number of occurrences of complaints concerning non-P235 Firestone tires. The sample consists of three-plants-by-9-production- years-by-9-calendar-year cells. As explained in the Data Appendix, we use a variety of sources to derive the total number of 
non-P235 tires produced in each plant each year. This variable is likely to be measured with error, so we constrain the coefficient to one in column 3 . In view of the likely impact of measurement error, it is surprising that the unconstrained production elasticity exceeds one (see column 2 and 5). The estimated effect for the Decatur-dispute period is reduced somewhat if we constrain the coefficient on log production to one.

Most importantly for our purposes, in all of the models the coefficient on the Decatur-plant-dispute-period interaction term indicates that Decatur had an elevated number of complaints involving tires produced during the labor dispute, other things equal. These results suggest that the high incidence of defective tires in the Decatur plant during the labor dispute was not unique to P235, as one would expect if labor strife was an important reason for the production of defective tires.

\section{Conclusion}

The evidence we have assembled suggesting that the labor dispute contributed to the production of many defective Firestone tires in the 1990s is circumstantial but broad and consistent; we think that the evidence pointing toward the role of labor strife is more persuasive and comprehensive than that in favor of the alternative hypotheses that have been proposed. The temporal patterns in all of the data sets we have examined indicate that a higher than expected rate of problems occurred in tires produced in Decatur, the plant with the most contentious labor relations, during their labor dispute. We can also rule out many other explanations - for example, the fact that high-speed stress tests conducted under uniform conditions indicated that tires produced in Decatur during the

\footnotetext{
${ }^{35}$ To avoid contaminating the sample by including P235 tires because of through the allocation of missing values, when we constructed the sample we eliminated all tires that might have been P235 tires, and then imputed the missing values for this subsample.
} 
labor dispute performed less well weighs against the hypothesis that changes in regional distribution patterns or the Ford Explorer was the root cause of the elevated defect rate during the labor dispute - but we cannot be certain that some unobserved factor did not change, causing defect rates to rise in the struck Decatur plant in the 1994-96 period, and then changed back. This would be a remarkable coincidence, and no such factor has yet been identified, but it is a possibility.

Unless another factor can be found that explains the sudden rises in defects in tires produced when B/FS demanded contract concessions from the union in stalled negotiations and again when replacement workers and recalled strikers worked side-byside, we think the weight of the evidence points to labor strife as being at the root of many of the defective tires.

Our results complement other findings concerning labor-management conflict. Freeman and Medoff (1984, p. 167) cite evidence suggesting that the union productivity effect in the underground bituminous coal industry varies sharply over time with the state of labor relations and management policies. Kleiner, Leonard and Pilarski(2002) study the impact of the industrial relations climate on productivity at a plant that assembles large aircraft. The evidence they present suggests that industrial relations events had short-term effects on productivity, which dissipated in the longer term. Katz, Kochan and Gobeille (1983) study the relationship between various plant-level measures of industrial relations and economic performance at General Motors, and find strong correlations between the industrial relations climate and productivity. Additionally, they find a strong correlation between some measures of industrial relations performance and the quality of production. Interestingly, the industrial relations measure with the strongest negative 
correlation with production of automobiles that did not pass inspection is the negotiation time required to reach a new contract agreement.

Ironically, an internal Bridgestone document obtained by the URW reportedly stated, "while it was nice to share a good relationship [with the union], it would no longer be in the company's interest." 36 The stock market valuation of B/FS fell from $\$ 16.7$ billion to $\$ 7.5$ billion in the four months after the recall was announced, and the top management of Bridgestone/Firestone has been replaced. The company also closed the Decatur plant in December 2001, and considered abandoning the Firestone brand name. If antagonistic labor relations were responsible for many of the defects, even indirectly, this episode would serve as a useful reminder that a good relationship between labor and management can be in both the company's and the union's interests.

More speculatively, our results raise the possibility that there may be costs associated with hiring replacement workers and labor strife that are not internalized or anticipated by labor or management, especially in industries that affect the public safety. We estimate that more than 40 lives were lost as a result of the excessive number of problem tires produced in Decatur during the labor dispute, and that number probably would have been more than twice as high if it were not for the tire recall. If the external costs were not taken properly into account by labor and management, then public policy could possibly play a valuable role by requiring more safety inspections for products manufactured during a strike or period of labor strife.

\footnotetext{
${ }^{36}$ See Franklin (2001; p. 122). This document was obtained by the union from an anonymous source, so it is unclear how much stock to put in it.
} 


\section{References}

Adams, Larry. "Software Helps You Mind Your APQPs." Quality Magazine, October 2000, available from http://www.qualitymag.com/articles/2000/oct00/1000f3.asp.

Barboza, David. "Firestone Workers Cite Lax Quality Control." The New York Times, September 15, 2000, p. C1.

Bierecree, Adrienne, "Capital Restructuring and Labor Relations: The International Paper Strike." In International Contributions to Labour Studies, Vol. 1, edited by Gerald Berk. Notre Dame, I.N.: Academic Press, 1991.

Bishop, Yvonne M.M.,; Fienberg, Stephen E.; and Holland, Paul W. Discrete Multivariate Analysis: Theory and Practice, Cambridge, M.A.: MIT Press, 1975.

Cameron, A. Colin, and Trivedi, Pravin. Regression Analysis of Count Data. Cambridge, U.K.: Cambridge University Press, Econometric Society Monograph, 1998.

Craypo, Charles. "Meathpacking: Industry Restructuring and Union Decline." In Contemporary Collective Bargaining in the Private Sector, edited by Paula B. Voos. Madison, W.I.: Industrial Relations Research Association, 1994.

Fehr, Ernst and Gächter, Simon. "Fairness and Retaliation." Journal of Economic Perspectives 14 (Fall 2000): 159-182.

Fogarty, Thomas. "Retirees cite production practices: Depositions in '92 case may shed light on recent problems, but company, unions dispute claims." USA Today, August 24, 2000.

Franklin, Stephen. Three Strikes. New York, N.Y.: The Guilford Press, 2001.

Freeman, Richard and Medoff, James. What Do Unions Do?. New York, N.Y.: Basic Books, 1984.

Ginsbach, Pam. "Labor Strife Found Key Factor in Production of Defective Tires at Bridgestone/Firestone." Daily Labor Report, Washington, D.C.: Bureau of National Affairs, January 11, 2002: AA-1.

Green, Hardy. On Strike at Hormel. Philadelphia, P.A.: Temple University Press, 1990.

Greenhouse, Steven. "Accord Reached in Dispute at Tire Company." The New York Times, November 7, 1996, p. A16.

House Committee on Commerce. "The Recent Firestone Tire Recall Action, Focusing on the Action As It Pertains To Relevant Ford Vehicles." Hearings before the Subcommittee on Telecommunications, Trade and Consumer Protection and the Subcommittee on Oversight and Investigations, September 6 and 21, 2000, Washington, DC: U.S. Government Printing Office, Serial No. 106-165, 2001. 
Katz, Harry C.,; Kochan, Thomas A.,; and Gobeille, Kenneth R. "Industrial Relations Performance, Economic Performance, and QWL Programs: An Interplant Analysis." Industrial and Labor Relations Review 37 (October 1983): 3-17.

Kleiner, Morris M.,; Leonard, Jonathan S.,; and Pilarski, Adam M. "How Industrial Relations Affect Plant Performance?: The Case of Commercial Aircraft Manufacturing." Industrial and Labor Relations Review 55 (January 2002): 195-218.

Meyer, Bruce. The Once and Future Union: The Rise and Fall of the United Rubber Workers, 1935-1995. Akron, O.H.: University of Akron Press, 2002.

Parks, James B. "Bridgestone face worldwide worker solidarity." AFL-CIO News, March 22, 1996a.

Parks, James B. "Bridgestone calls most back; USWA fight will continue on fair labor practices." AFL-CIO News, October 11, 1996 b.

Pinkerton, James. "Firestone attorneys put blame on Ford in rollover lawuit." The Houston Chronicle, August 14, 2001 a, Business Section, p. 1.

. "Doctor tells jurors how Firestone tires failed." The Houston Chronicle,

August 15, 2001 b, p. A21.

Poynter, Dan. Parachuting: A Skydiver's Handbook, 6th edition. Santa Barbara, C.A.: Para Publishing, 1992.

Rabin, Mathew. "Incorporating Fairness into Game Theory and Economics." American Economic Review 83 (December 1993): 1281-1303.

Rosenblum, D. Jonathen. Copper Crucible. Ithica, N.Y.: ILR Press, 1995.

Rubin, Donald. Multiple Imputation for Nonresponse in Surveys. New York, N.Y.: John Wiley, 1987.

Sabath, Donald. "Goodyear Workers Stand Firm." The Plain Dealer, April 22, 1997, p. C1.

Skertic, Mark. "Firestone retirees cite pressure to produce." Chicago Sun Times, October 27, 2000.

Tire Business, "Workers Strike Quebec Plant", October 30, 1995.

U.S. Department of Labor, Bureau of Labor Statistics, Compensation and Working Conditions, January 1996, pp. 2-3.

Whitford, Marty, "Bridgestone Unit to Show First Full-Year Profit," Rubber \& Plastics News, Crain Communications, January 17, 1994, p. 6. 


\section{Data Appendix}

\section{A. NHTSA complaints data}

The NHTSA micro data set is publicly available from the NHTSA web page. ${ }^{37}$ NHTSA began compiling complaints regarding Firestone tires in February 2000, and ceased in June 2001. The data set consists of self-reported consumer complaints from the Office of Defect Investigation (ODI) Consumer Complaint Database, insurance company records (eg. State Farm Insurance), police reports, reports by safety organizations (eg. Safety Forum), and the Fatality Analysis Reporting System (FARS).

The data set includes a variable for the date that the complaint was submitted. This variable is somewhat mislabeled as conversations with NHTSA employees revealed that in many cases the reporting date is listed as the first instance the consumer reported the problem to authorities, though not necessarily to NHTSA, when such initial records exist. For example, if a consumer filed a report with the police in February 1994, and the police contacted NHTSA in July 2000 regarding this report, the reporting date is listed as February 1994.

Each record in the NHTSA data set includes a summary of the events leading to the complaint. We reviewed each summary and dropped 4 of the 5,193 records whose summary did not indicate a problem with a tire, or concerned problems with other brands of tires.

The tires in the NHTSA database were grouped into P235/75R15's (P235) and nonP235/75R15's (non-P235). There were records where only some fragment of

\footnotetext{
${ }^{37}$ www.nhtsa.dot.gov/hot/Firestone/Update.html
} 
"P235/75R15" was reported. These partial reports were coded as missing, unless the corresponding tire model was something other than ATX, ATX II or Wilderness AT, in which case the size was coded as non-P235.

In 3,374 cases the DOT code of the failed tire is reported. If the DOT code is complete it is possible to infer the plant in which the tire was produced, as well as the week and the year of production. The first two characters of the ten-digit DOT code indicate the plant code, while the last three digits give the week and year of production. In many cases only parts of the DOT code are reported. In 11 cases only the date of production are included in the DOT code; in 652 cases partial DOT codes include the plant identification and omit the date of production.

There are six records in which the failure date occurs before the year of production - at least one must be wrong. Both dates are coded as missing in this instance.

\section{Multiple Imputations}

In many cases the NHTSA data lacked information on the seven variables that were used as variables directly in the discrete count models, or were used to identify the relevant sub-samples used for our analysis. The variables for which complete data are required to conduct our analysis are tire size, tire model, plant, year of failure, year of production, month reported and year reported. Within the sub-sample of complaints that are missing at least one of the seven variables, about twenty-five percent are missing plant, year of production and age, i.e. the DOT code. Table A1 summarizes the missing values of the key variables in the data set for the seven variables used in our analysis.

To handle missing data, ten data sets were created, each drawing a new value for the missing records. For each observation, the missing values were randomly assigned 
from the joint distribution of those variables, conditional on a set of non-missing variables that depended on the particular missing variables. Specifically, the NHTSA micro data set on tire complaints include variables $y_{1}, \ldots, y_{7}$, which we use to impute, and variables $z_{1}, \ldots, z_{L}$, which we use to condition on. Variables $y_{1}$ through $y_{7}$ are year of production, plant, year of failure, year reported, month reported, tire size and tire model. Variables $z_{1}$ through $z_{L}$ include vehicle model year, vehicle mileage at time of failure, vehicle model and vehicle make as well as the non-missing variables from $y_{1}$ through $y_{7}$. Values of z may be missing as well.

The goal for imputation is to construct a fully classified $y_{1} \times y_{2} \times \cdots \times y_{7}$ contingency table. Assume $m$ observations are fully classified in the NHTSA data, and $n-m$ are partially classified because of missing data. We begin by partitioning the records according to which of the $y$-variables are missing, so within some partition $\mathbf{P}_{j}$ all the records are missing values for the same variables; $\mathbf{P}_{0}$ is the set of records with nonmissing data for this set of variables. Let $\mathbf{Y}_{j}$ denote the set of variables that are missing in partition $\mathbf{P}_{j}$. We assign to each partition $\mathbf{P}_{j}$ a set of conditioning variables $\mathbf{Z}_{j}$ that are a subset of the variables $z_{1}, \ldots, z_{L}$ and the $y_{1}, \ldots, y_{7}$ variables. Next we link the records in $\mathbf{P}_{j}$ to the non-missing records in set $\mathbf{P}_{0}$ by matching on the conditioning variables in $\mathbf{Z}_{j}$ to form the empirical distribution of $\mathbf{Y}_{j}$ conditional on $\mathbf{Z}_{j}, \mathbf{P}\left(\mathbf{Y}_{j} \mid \mathbf{Z}_{j}\right)$. We then randomly draw values to impute the missing values of records in $\mathbf{P}_{j}$ from this conditional distribution. This process is repeated 10 times to generate 10 data sets. 
We chose different conditioning sets for each combination of missing variables to exploit a priori information on how variables covary, resulting in more efficient imputations. For example, to impute the age variable we used year of production and vehicle miles (in bins), as these will account for more variation in age than, say, tire size and plant. Table A2 summarizes the conditioning variables for each set of missing variables in the original micro data set. For continuous conditioning variables we grouped variables into bins, choosing bin sizes large enough to ensure that the empirical distributions arising from the non- missing sub-sample were not degenerating to a few points. For observations that were missing all seven variables we drew from the empirical unconditional joint distribution of the available data.

As an example, consider all observations for which just the DOT code is missing, implying that we are missing records for plant and year of production for these observations. As seen in table A1, plant and year of production represent the most common set of missing values in the data set, with 1,285 missing observations for these two variables. To impute these variables, we conditioned on the reported vehicle model year and number of miles on the vehicle. Vehicle model year clearly covaries with year of production, and together with vehicle miles may account for significant variability in tire age. It is possible that plant is essentially orthogonal to both of these conditioning variables, suggesting that a large part of the imputation variability is coming from the plant dimension in the draws. Both conditioning variables were grouped into bins. The vehicle miles variable was grouped into six bins: 0-14,999, 15,000-29,999, 30,00059,999, 60,000-89,999, >89,999, and miles missing. Vehicle model year was grouped into six bins with cut points at 1991, 1994, 1997, 2000 and missing. The mechanics of the imputation first involves grouping the subset of records with complete year of 
production, plant, and age data by the conditioning variables to create an empirical distribution of year of production, plant and age conditional on vehicle miles and vehicle model year. For each missing observation we then match the conditioning variables in the missing sub-sample with the corresponding variables in the complete data set and randomly assign values from the correspond ing conditional distribution. Provided that data are missing at random conditional on the Z's, our approach should provide consistent estimates.

The imputed data sets for the non-P235 tires differed from the P235's. To ensure that no P235 tires were inadvertently mixed into the non-P235 sub-sample, and perhaps drive the estimates, we used only observations know to be non-P235's and imputed on the remaining variables. Because the non-P235 sample was smaller, we used somewhat different sets of conditioning variables, as well as bin sizes. As such, the non-P235 estimates are based on ten different complete micro data sets than the P235's.

Once ten micro data sets were created we aggregated each data set into plant-byyear-of-production-by-age cells. The outcome variable (number of complaints, fatal accidents, or injurious accidents) is a count variable recording the number of failures per plant-by-year-of-production-by-age. Because we then aggregate the imputed micro data sets into cells that determine most of the right-hand side variables in the estimation, our multiple imputation method is different than the ones commonly used in the literature.

Count regression models were estimated for each of the 10 imputed data sets.

Coefficient estimates $(\hat{\beta})$ reported in the paper are simply the average of the 10 estimates. An essential feature of the multiple imputation method is that the variancecovariance of $\hat{\beta}$ is the sum of between and within-imputation variability. Specifically, 
standard errors were computed as $\sqrt{\frac{1}{10} \sum_{i=1}^{10} s_{i}{ }^{2}+\sigma_{\beta}^{2}}$, where $s_{i}^{2}$ is the sampling variance of each individual estimate and $\sigma_{\beta}^{2}$ denotes the within-imputation variance, which is just the variance of the estimates across the 10 imputed data sets, $\operatorname{Var}\left(\hat{\beta}_{1}, \ldots, \hat{\beta}_{10}\right)$.

An alternative to the imputation technique we utilize is the Expectation Maximum (EM) algorithm. For our problem this would involve constructing a complete $y_{1} \times y_{2} \times \cdots \times y_{7}$ contingency table from the fully classified records, and partially classified contingency tables from the partially classified records. Cell probabilities would be computed from the relative proportions of cell entries in the complete contingency table and tires would be allocated according to these probabilities, conditional on belonging to a partially classified table. A practical drawback to this approach, however, is that it becomes difficult to take advantage of the additional information available from the conditioning variables, $z_{1}, \ldots, z_{L}$. We could estimate the full $y_{1} \times \cdots \times y_{7} \times z_{1} \cdots \times z_{L}$ contingency table, but we lack sufficient degrees of freedom to do so. In our multiple imputation approach we simplified this by imposing conditional independence assumptions for certain associations of the $z$ 's and $y$ 's. It is possible to impose such assumptions using the EM-algorithm by distributing partially classified counts into the fully classified contingency table using estimated conditional probabilities subject to a set of constraints on the estimated probabilities [Bishop, Fienberg and Holland, 1975]. Nevertheless, we chose to use a simpler hotdecking-type approach because it is transparent and easy to implement. Because the estimates are similar in the non-imputed data, we suspect our results would be similar had we used an EM algorithm. 


\section{B. Non-P235 Production Data}

Total production, or production of non-P235 tires, by plant and year is unavailable. However, using a combination of different sources we can construct what we believe is a reasonable estimate. The non- $\mathrm{P} 235$ production data were constructed by combining plant capacity figures provided by Modern Tire Dealer with historical capacity utilization rates for motor vehicles and parts obtained from the Federal Reserve web page. ${ }^{38}$ Additional adjustments were made to account for documented reductions in capacity utilization at the Decatur plant during the strike.

Modern Tire Dealer, a trade magazine, provided us with manufacturer's reported capacity numbers for all Firestone plants from 1990 through 2000. The capacity figures represent the number of tires plants can produce per day. We multiplied these capacities by the Federal Reserve motor vehicles and parts capacity utilization rates for January of each year, yielding estimated daily production by year and plant. These capacity utilization rates range from $60 \%$ in 1991 to $84 \%$ in 1995 . We multiplied these resulting daily production figures by 350 , which was required to match our 2000 estimate of total Firestone production to an independent estimate of total production obtained by calculating Firestone's share of total US tire production in 2000.

We adjusted Decatur's 1995 production to account for reduced production in this period as documented in the trial documents of Bridgestone/Firestone v. Doherty, a court case involving unemployment insurance eligibility. ${ }^{39}$ Trial records suggest that production at the Decatur plant in 1995 was $62 \%$ of production in 1994. Decatur's production in the second half of 1994, after the strike began, was 641,325 tires, according

\footnotetext{
${ }^{38}$ http://www.federalreserve.gov/releases/G17/download.htm
} 
to Congressional testimony. ${ }^{40}$ We assumed production equaled the daily capacity rate times the Federal Reserve utilization rate before the strike commenced in July 1994, and that 641,325 tires were produced in the remainder of the year. Joliette's production estimates were adjusted to account for the fact that the plant was on strike for two months in 1995 and four months in 1996. During this time salaried workers and management produced a smaller number of tires. An article in Tire Business quotes the president of the local union at Joliette, Jim Bourret, indicating that production was down $87 \%$ as compared to before the strike. ${ }^{41}$ Thus, production at Joliette for 1994 and 1995 was calculated as the weighted average of regular production (capacity times utilization) and thirteen percent of regular production, using as weights the number of months of the year the plant was on strike. Finally, non-P235 production was calculated as total production less P235 production.

\section{Monthly Production Data}

We have annual P235 production by plant, but not monthly data. We used the annual data and other sources to construct our best guess for monthly production of P235 tires in the Decatur, Joliette and Wilson plants.

Within the year, monthly production in 1993 was assumed to follow a linear trend proportional to the annual trend in P235 production from 1991 to 1993 . A constant was then added so that the sum of monthly production in 1993 matched the yearly figure.

As noted above, Decatur's production in 1994 after the strike began was at 641,325 tires, about 14 percent of Decatur's total production for the year. We assumed

\footnotetext{
${ }^{39}$ Opinion of the court, Bridgestone/Firestone v. Doherty, No. 4-98-0029. www.state.il.us/court/Opinions/A...t/1999/4thDistrict/May/HTML/4980029.html

${ }^{40}$ House Committee on Commerce (2000; p. 139).
} 
that P235 production for August through December of 1994 was 14 percent of total P235 production for 1994. We assumed that there was a nominal amount of production in August and September 1994, the first two months of the strike. For both months we set production at 5,000 tires. This is probably a reasonable assumption because employment data indicate that there were very few workers in the Decatur plant during these first months (see Figure 7). Since the strike began approximately in the middle of July 1994, we assumed production in the first half of July was half of June production, and production in the second half of July was half of August production.

For the first six months of 1994 we assume that monthly production follows the same linear trend as 1993, rescaled so that the sum of production for the first seven months of 1994 equals 86 percent of total P235 production for the year. For the last three months we linearly interpolated the remaining 14 percent of total P235 production for the year and rescaled.

Information from the trial documents of Bridgestone/Firestone v. Doherty (a case involving unemployment benefits) were used to construct monthly production for the first five months of 1995. These documents specify the plant productivity (in terms of pounds of tires produced) for each of the first six months of 1995 relative to the corresponding months in 1994. For example, production in March of 1995 was 57\% of production in March 1994. For the remaining seven months of 1995 we linearly interpolated and rescaled to match the total. Monthly production estimates for Decatur in 1996 were obtained by interpolating annual production.

\footnotetext{
${ }^{41}$ Tire Business, “Workers Strike Quebec Plant”, October 30, 1995.
} 
Production over the months of 1993 in the Wilson and Joliette plants was assumed to follow the same linear trend in annual production in those plants that held from 1991 to 1993 , and the first month of the year was set to make the annual 12-month total match the total production for the year. Production for 1994, 1995 and 1996 were linearly interpolated and rescaled. Production for the last four months of 1995 and first two months of 1996 in Joliette were adjusted to take account of the strike at that plant; information in Tire Business indicated production was down $87 \%$ during the strike.

Although our procedure for estimating monthly production undoubtedly is imperfect, in each plant the sum of production over the 12 months of every calendar year is controlled to equal the known annual production figure for that calendar year, so it is unlikely that the estimates are very far off. 
Figure 1: Claims per Million Firestone ATX Tires Produced, by Age of Tire at Failure, Production Year and Plant

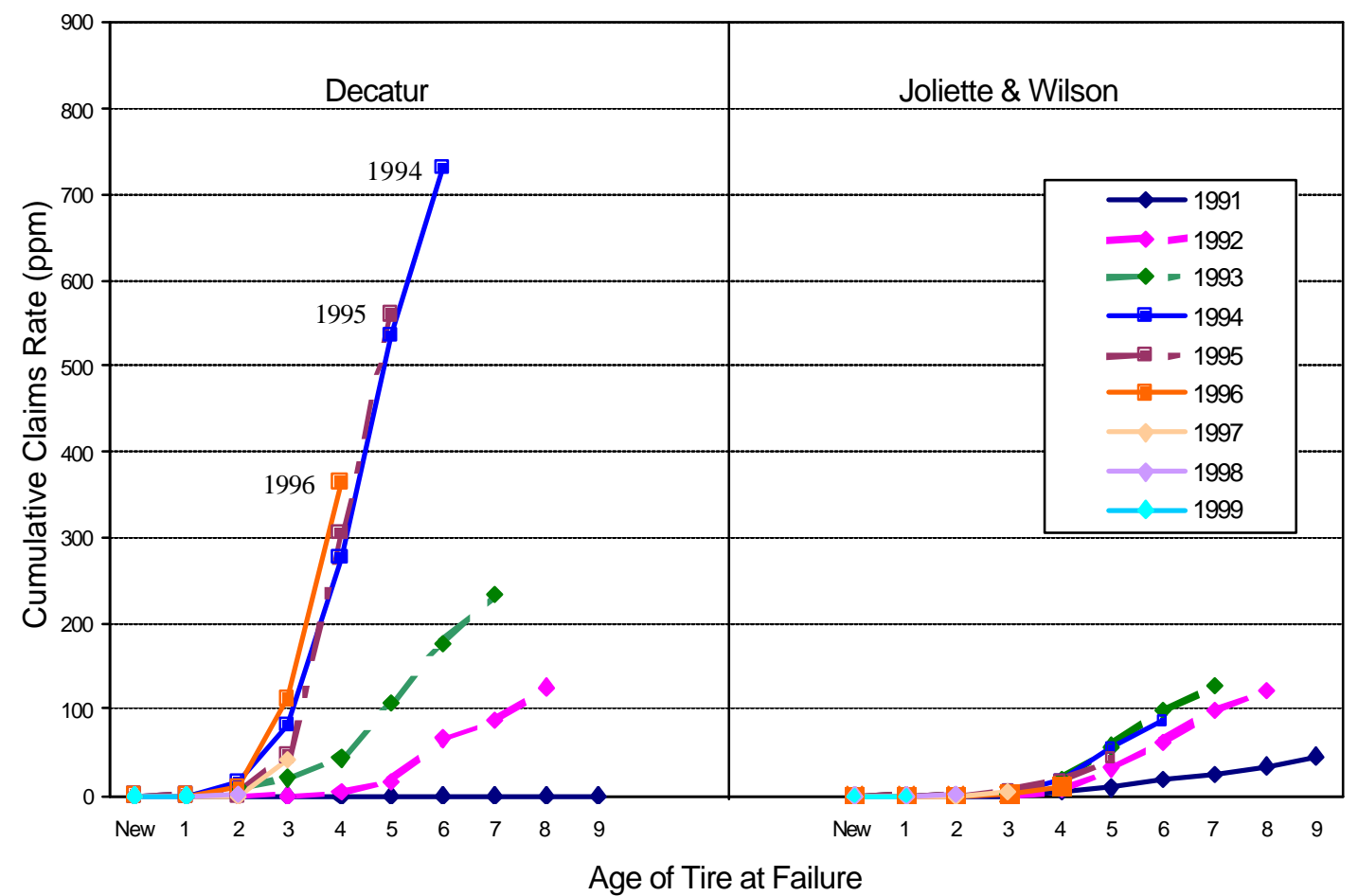

Source: Authors' calculations based on Firestone claims data submitted to NHTSA. Claims are for personal injury or property damage involving Firestone ATX tires prior to 2000. 
Figure 2: Complaints Registered by NHTSA per Million P235/75R15 Firestone Tires Produced, by Age of Tire, Production Year and Plant, Non-Imputed Data

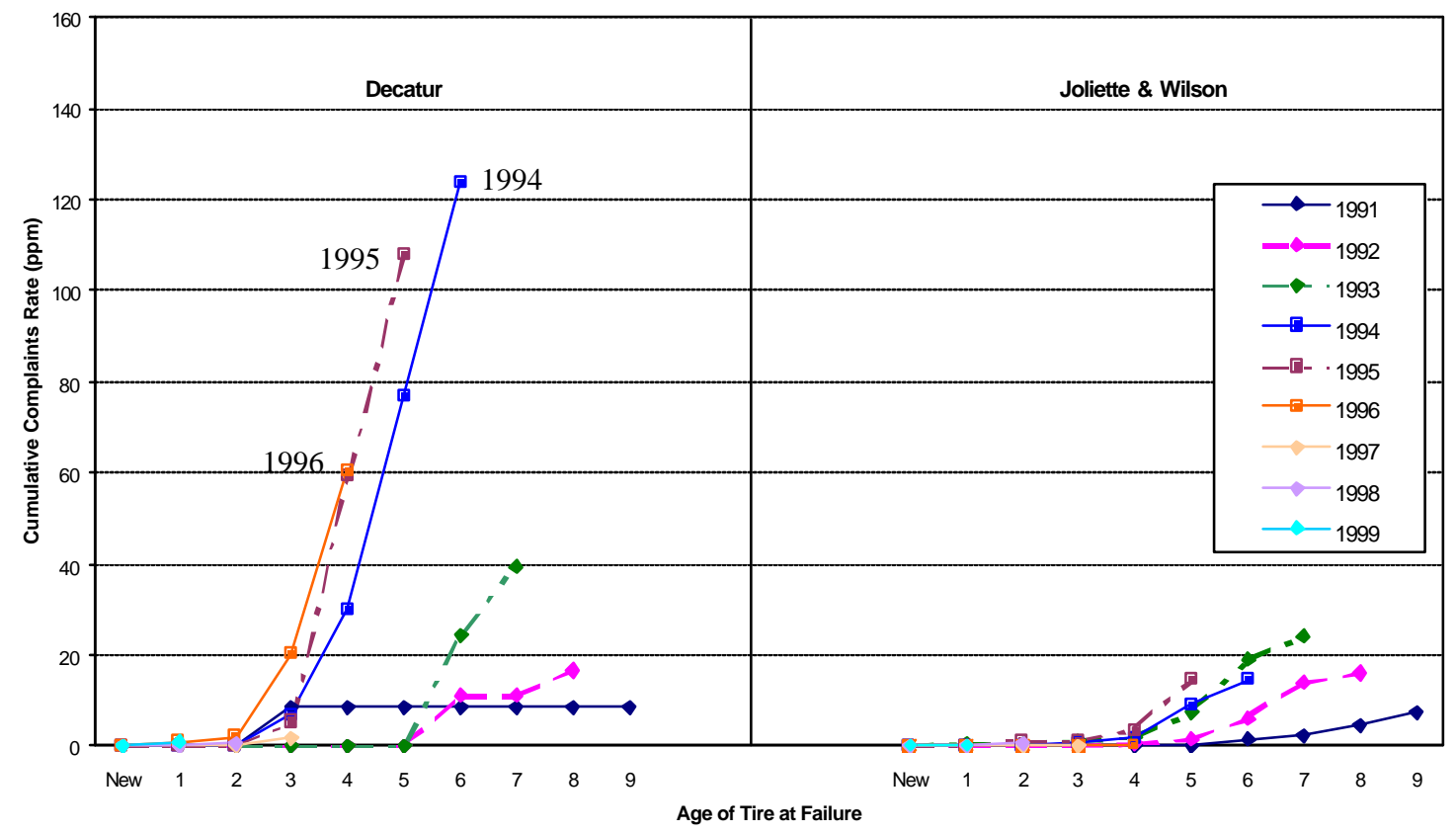

Source: Authors' calculations based on NHTSA and Safety Forum data. Complaints are concerning defects in 199199, reported prior to August 2000. Observations with missing data are excluded. Sample includes ATX and Wilderness P235/75R15 tires. 
Figure 3: Complaints Registered by NHTSA per Million P235/75R15 Firestone Tires Produced, by Age of Tire, Production Year and Plant; Average of 10 Imputed Data Sets

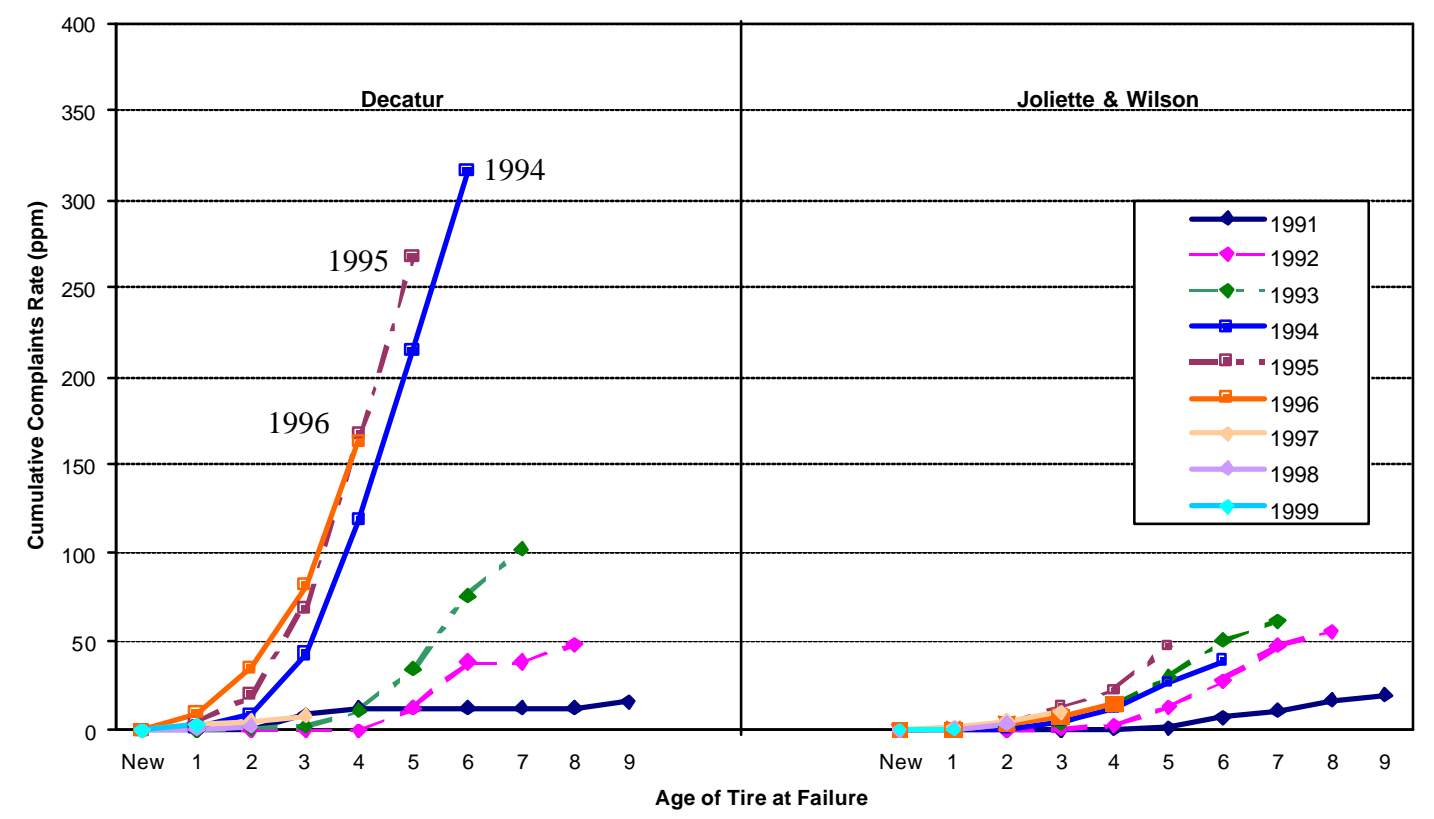

Source: Authors' calculations based on NHTSA and Safety Forum data. Complaints are concerning defects in 1991-99, reported prior to August 2000. See text for explanation of how missing values were allocated. Sample includes ATX and Wilderness P235/75R15 tires. 
Figure 4: Number of Accidents with Fatalities per Million Frestone P235/75R15 Tires Produced by Age of Tire, Production Year and Plant; Average of 10 Imputed Data sets

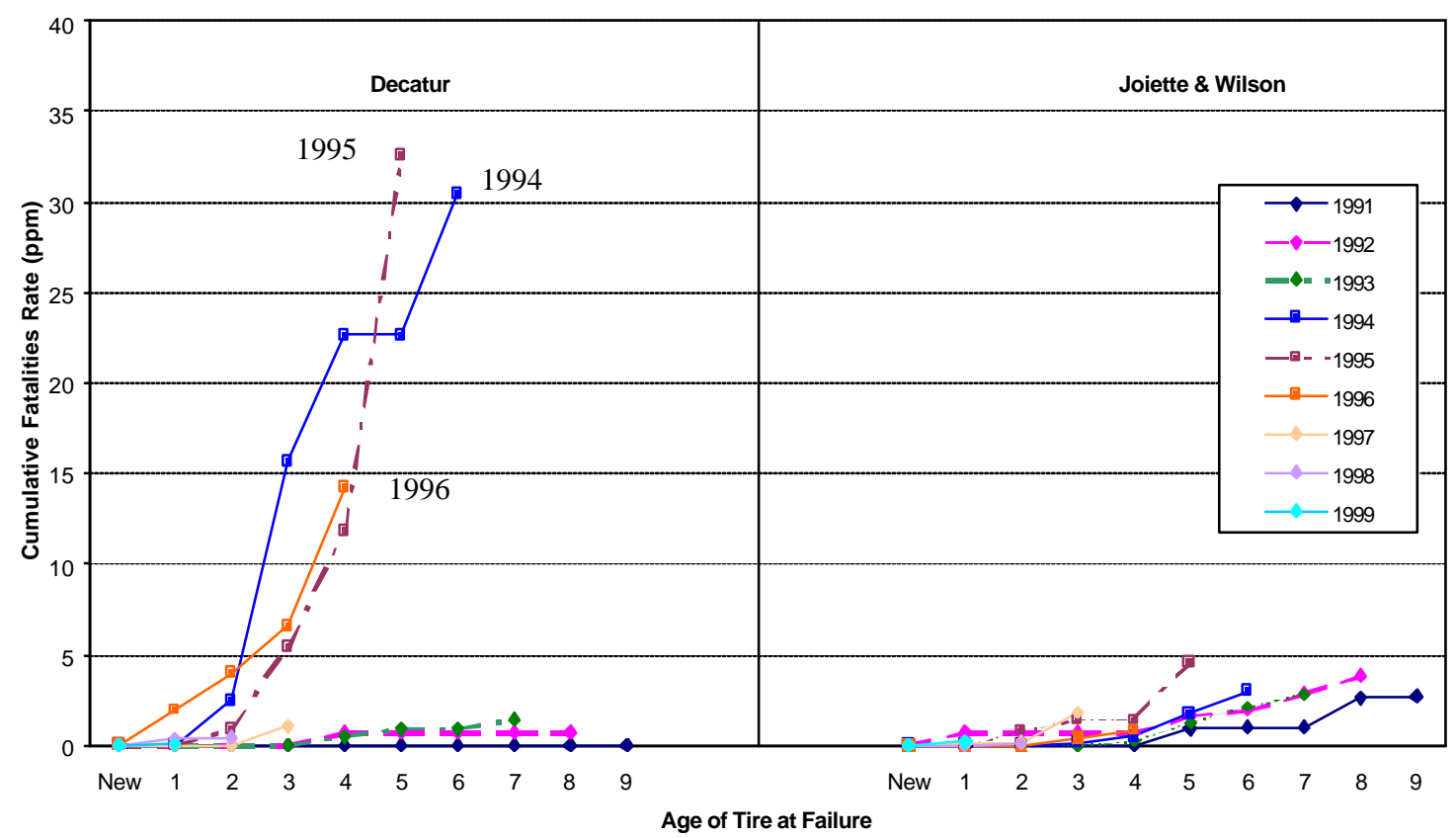

Source: Authors' calculations based on NHTSA and Safety Forum data. Sample includes ATX and Wilderness P235/75R15 tires. Accidents occurred between 1991 and 1999, and could have been reported at any time after 1991. 
Figure 5: High speed stress tests: Box plots of miles traveled before burst

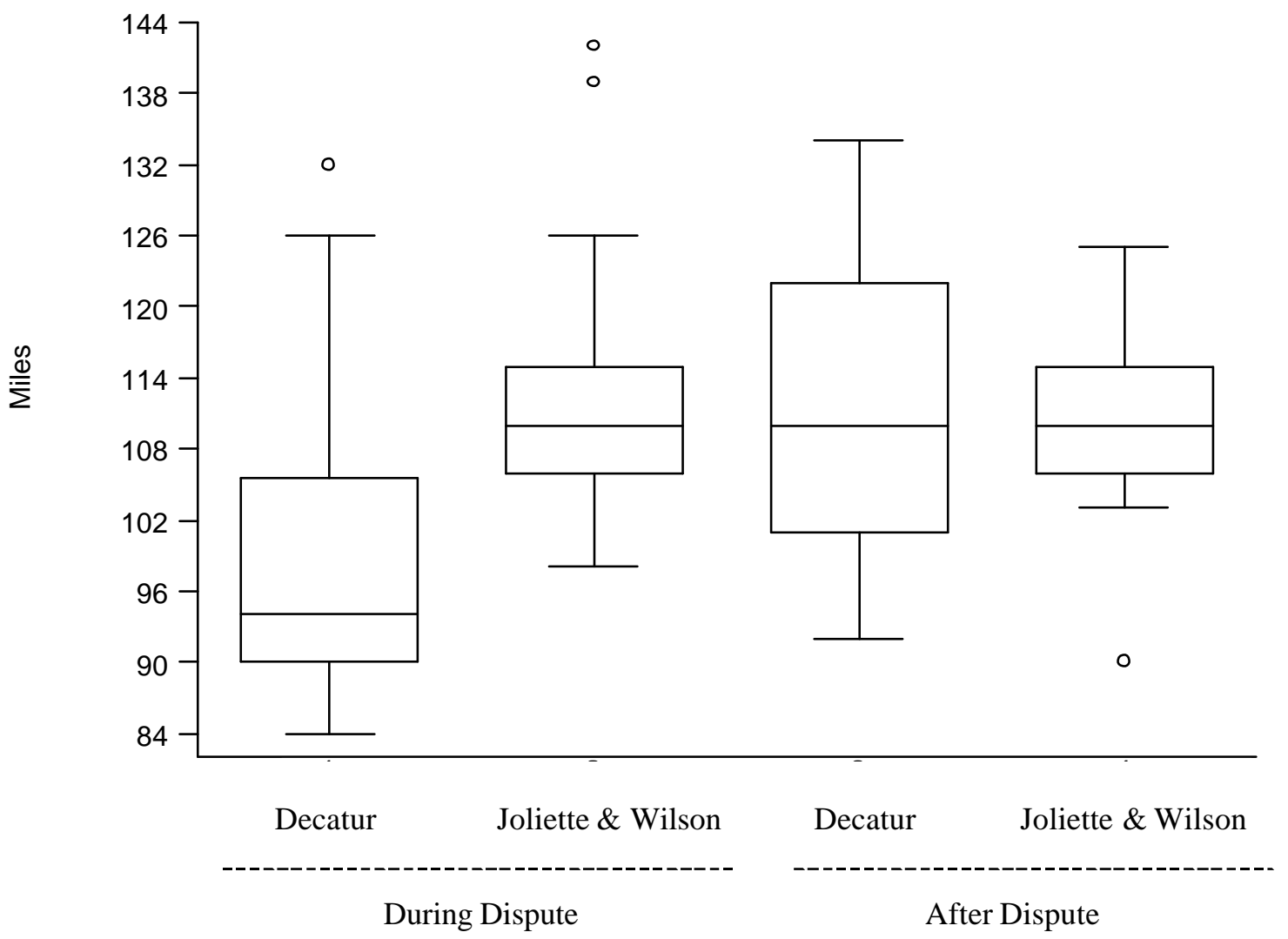

Source: Authors' calculations from Firestone U1 test data reported to House Committee on Commerce (2001). Tests in this sample were conducted 1995-98. The bottom of each box represents the value at the $25^{\text {th }}$ percentile, and the top represents the value at the $75^{\text {th }}$ percentile. The middle line indicates the distance traveled before the median tire burst. The vertical lines (known as upper and lower adjacent hinges) extend to the first data point encountered within 1.5 times of the interquartile range from the edge of the box. Observations that lie beyond the upper and lower adjacent hinges are indicated by a circle. 
Figure 6: Number of Complaints Concerning P235 Tires Produced in Decatur, by Month.

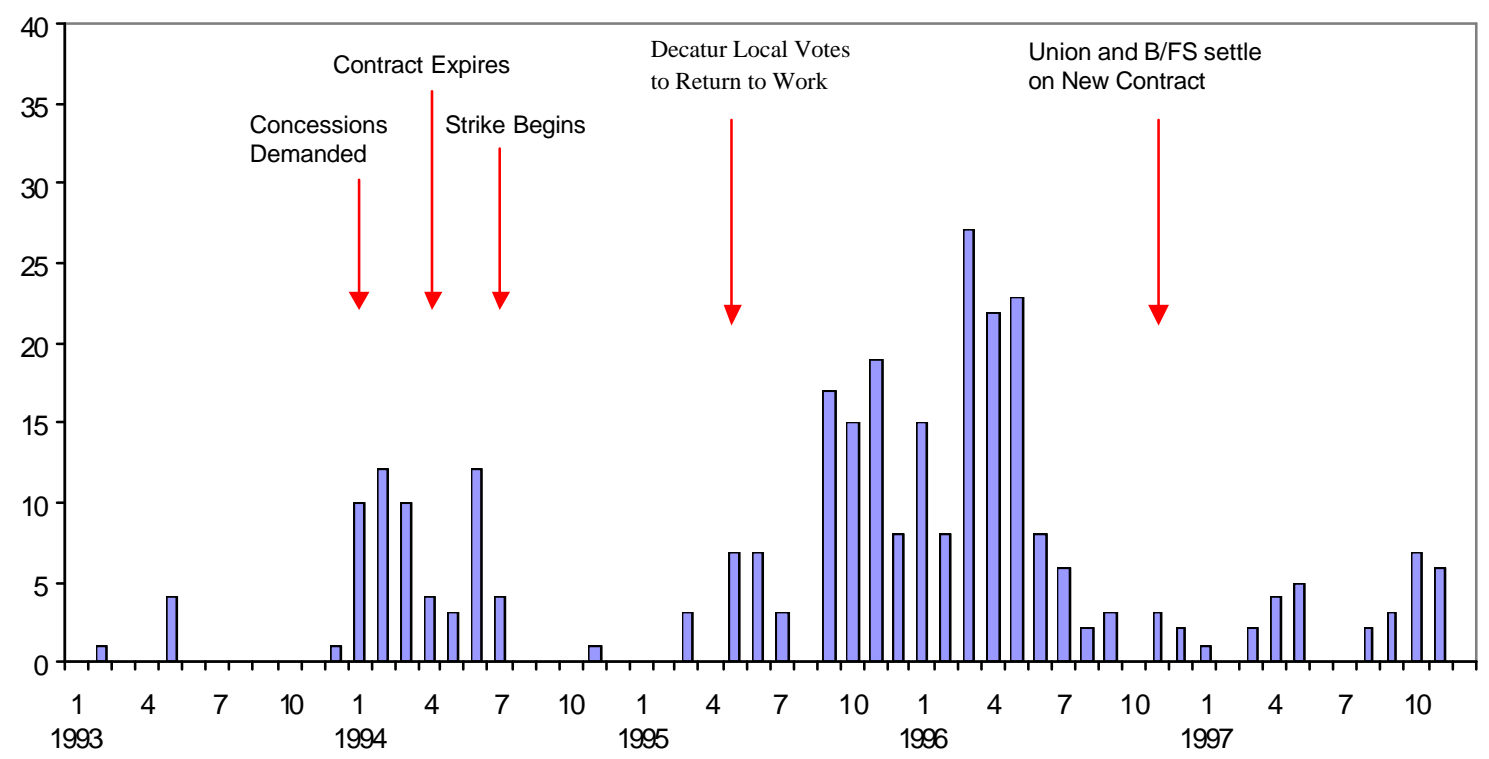

Source: Authors' calculations based on NHTSA complaints data. Records with missing data are excluded.

Figure 7: Number of Permanent Workers, Replacement Workers and Estimated Complaints per million tires produced by Month, Decatur Plant.

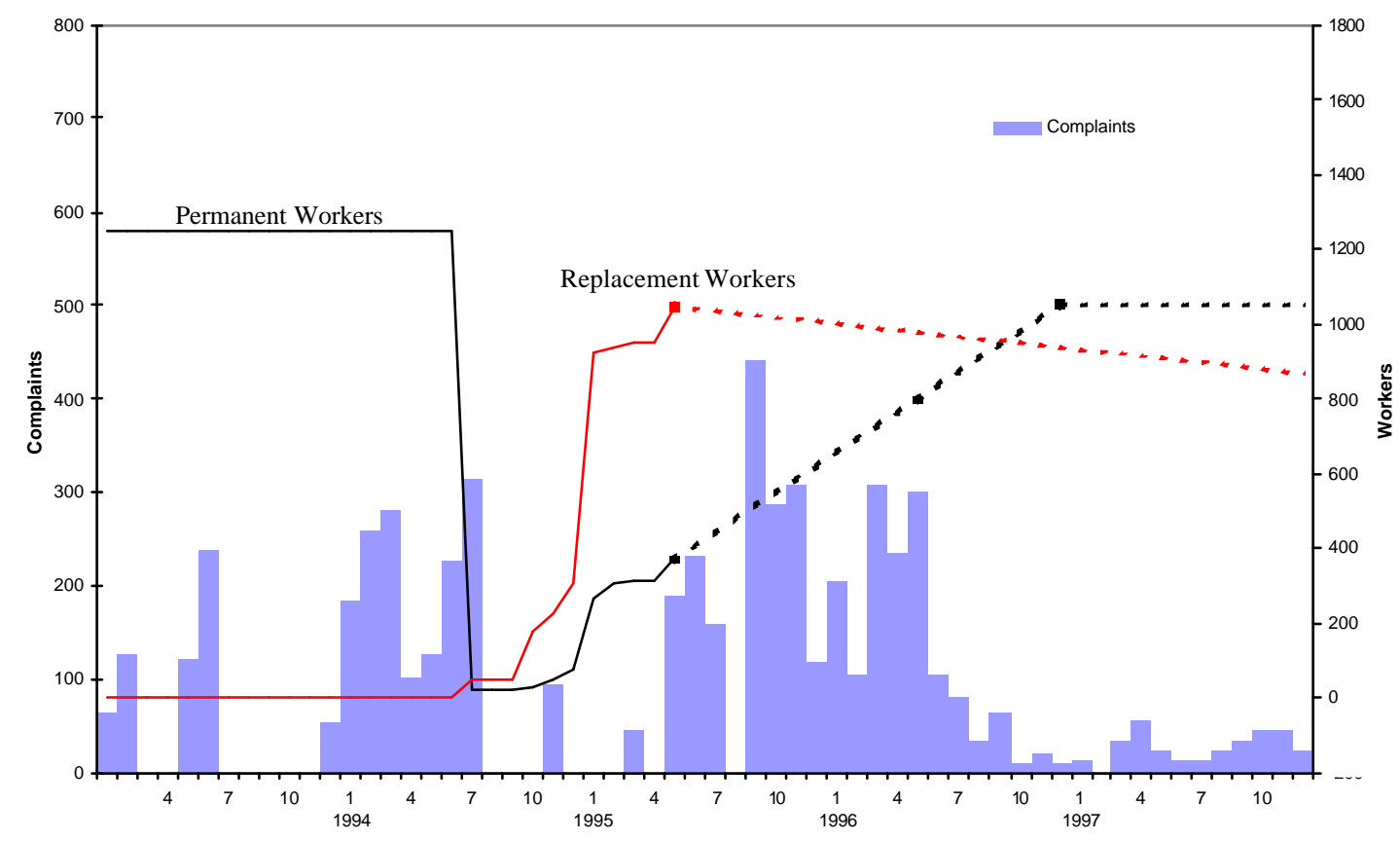

Source: Authors' calculations based on NHTSA complaints data, estimated monthly production (see Appendix), press reports and Firestone documents submitted to House Committee on Commerce (2001). Dashed lines indicate estimates of employment; blocks indicate specific data points. 
Figure 8: Difference in the Number of Complaints per million Tires Produced by Month: Decatur Plant minus Joliette and Wilson Plants.

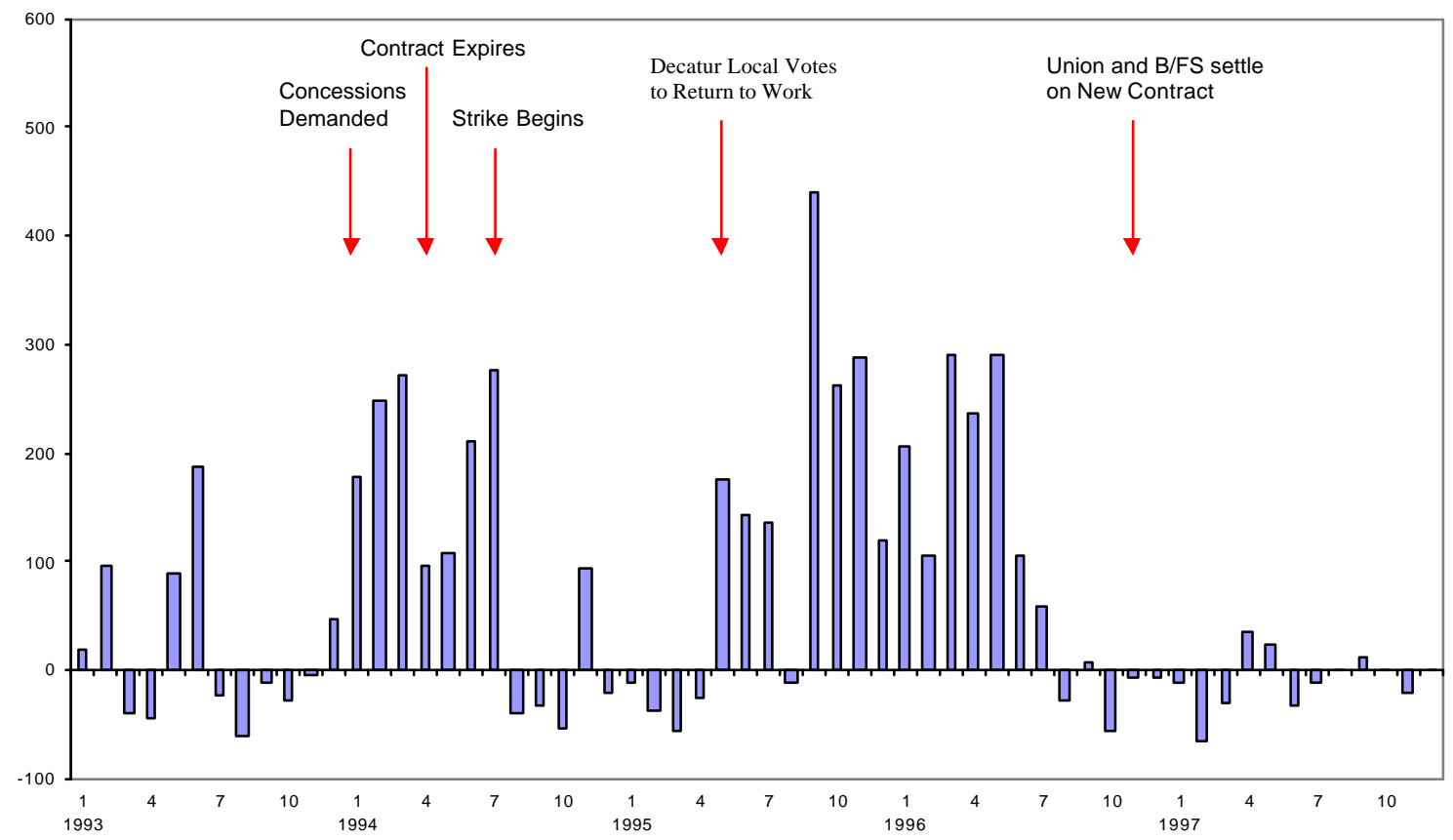

Source: Authors' calculations based on NHTSA complaints data. Records with missing data are excluded.

Figure 9: Difference in the Number of Claims per million Tires Produced by Month: Decatur Plant minus Joliette and Wilson Plants

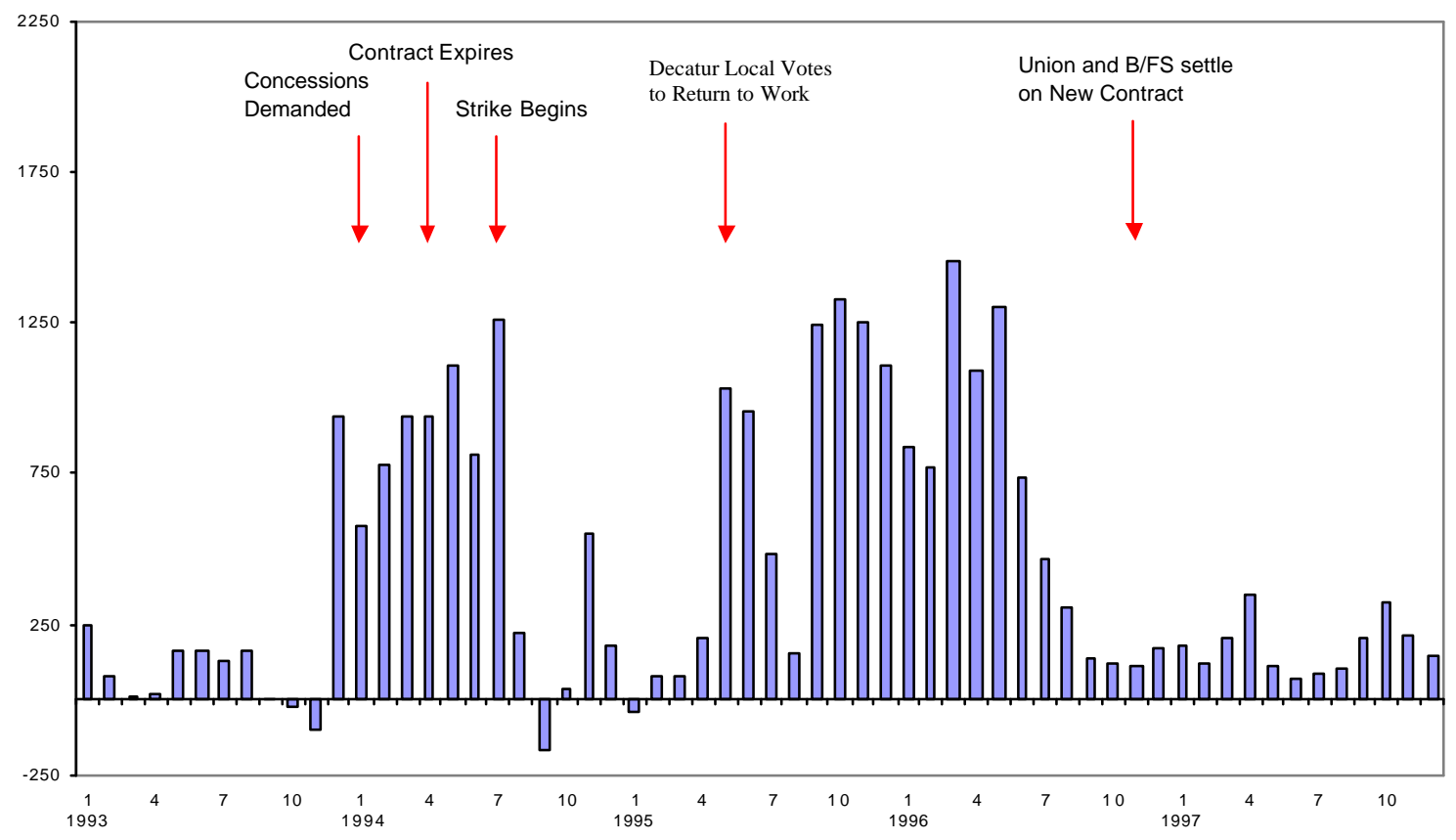

Source: Authors' calculations based on Firestone claims data. 
Table 1: Total Production of Size P235/75R15 Tires, Bridgestone/Firestone Plants, January 1991-March 2000

\begin{tabular}{|c|c|c|c|c|}
\hline$\underline{\text { Plant }}$ & $\begin{array}{r}\text { Number of ATX \& } \\
\text { Willderness Tires } \\
\end{array}$ & Percent of Total & $\begin{array}{r}\text { Claims per } \\
\text { Million ATX } \\
\text { Tires Produced } \\
\end{array}$ & $\underline{\text { Notes }}$ \\
\hline Aiken, SC & $1,442,115$ & $6.9 \%$ & NA & $\begin{array}{l}\text { Plant began operation in } \\
1999\end{array}$ \\
\hline Decatur, IL & $6,408,584$ & $30.5 \%$ & 356.0 & $\begin{array}{l}\text { Strike from July } 1994 \\
\text { to December } 1996 ; \\
1,048 \text { replacement } \\
\text { workers }\end{array}$ \\
\hline Joliette, Quebec & $5,638,302$ & $26.9 \%$ & 58.9 & $\begin{array}{l}\text { Strike from August } \\
1995 \text { to February 1996; } \\
\text { no replacement workers }\end{array}$ \\
\hline La Vergne, TN & 455,157 & $2.2 \%$ & NA & No strike \\
\hline $\begin{array}{l}\text { Oklahoma City, } \\
\text { OK }\end{array}$ & 530,515 & $2.5 \%$ & 44.1 & $\begin{array}{l}\text { Strike from July } 1994 \\
\text { to December } 1996\end{array}$ \\
\hline Wilson, NC & $6,503,642$ & $31.0 \%$ & 142.0 & Nonunion; no strike \\
\hline Total & $20,978,315$ & $100.0 \%$ & & \\
\hline
\end{tabular}

Notes: P235/75R15 tires include ATX, ATXII and Wilderness AT tires. Aiken produced only Wilderness tires.

Data Sources: Production derived from Safety Forum spreadsheet. Claims per million taken from chart submitted by Firestone to House Committee on Commerce, and pertains to property damage and personal injury claims for ATX size P235/75R15 tires. 
Table 2: Means of Data used in Aggregate Analysis of ATX and Wilderness AT P235/75R15 Tires

\begin{tabular}{|c|c|c|c|c|}
\hline & \multicolumn{2}{|c|}{ Claims } & \multicolumn{2}{|c|}{$\begin{array}{l}\text { Complaints (with imputations } \\
\text { for missing values) }\end{array}$} \\
\hline & $\begin{array}{l}\text { Unweighted } \\
\text { Means } \\
\text { (1) }\end{array}$ & $\begin{array}{l}\text { Weighted Means } \\
\text { (2) }\end{array}$ & $\begin{array}{c}\text { Unweighted Means } \\
\text { (3) }\end{array}$ & $\begin{array}{c}\text { Weighted } \\
\text { Means } \\
(4) \\
\end{array}$ \\
\hline $\begin{array}{l}\text { Number of Claims or } \\
\text { Complaints }\end{array}$ & $\begin{array}{l}12.10 \\
{[29.37]}\end{array}$ & --- & $\begin{array}{c}5.81 \\
{[10.88]}\end{array}$ & --- \\
\hline Log Production & $\begin{array}{l}13.11 \\
{[0.71]}\end{array}$ & $\begin{array}{l}13.37 \\
{[0.56]}\end{array}$ & $\begin{array}{l}13.11 \\
{[0.70]}\end{array}$ & $\begin{array}{l}13.35 \\
{[0.55]}\end{array}$ \\
\hline Proportion ATX & $\begin{array}{c}0.84 \\
{[0.32]}\end{array}$ & $\begin{array}{c}0.90 \\
{[0.19]}\end{array}$ & $\begin{array}{c}0.84 \\
{[0.32]}\end{array}$ & $\begin{array}{c}0.89 \\
{[0.21]}\end{array}$ \\
\hline $\begin{array}{l}\text { Proportion Original } \\
\text { Equipment }\end{array}$ & $\begin{array}{c}0.62 \\
{[0.24]}\end{array}$ & $\begin{array}{c}0.52 \\
{[0.28]}\end{array}$ & $\begin{array}{c}0.62 \\
{[0.24]}\end{array}$ & $\begin{array}{c}0.53 \\
{[0.28]}\end{array}$ \\
\hline Age & $\begin{array}{c}2.67 \\
{[2.22]}\end{array}$ & $\begin{array}{c}3.83 \\
{[1.40]}\end{array}$ & $\begin{array}{c}2.67 \\
{[2.22]}\end{array}$ & $\begin{array}{c}3.55 \\
{[1.54]}\end{array}$ \\
\hline Age Squared & $\begin{array}{c}12 \\
{[15.47]}\end{array}$ & $\begin{array}{c}16.63 \\
{[12.02]}\end{array}$ & $\begin{array}{c}12 \\
{[15.47]}\end{array}$ & $\begin{array}{c}15.24 \\
{[12.21]}\end{array}$ \\
\hline Decatur dum. (1=yes) & $\begin{array}{c}0.33 \\
{[0.47]}\end{array}$ & $\begin{array}{c}0.57 \\
{[0.50]}\end{array}$ & $\begin{array}{c}0.33 \\
{[0.47]}\end{array}$ & $\begin{array}{c}0.53 \\
{[0.50]}\end{array}$ \\
\hline $\begin{array}{l}\text { Dispute period dum., defined } \\
\text { as 1994-96 (1=yes) }\end{array}$ & $\begin{array}{c}0.33 \\
{[0.47]}\end{array}$ & $\begin{array}{c}0.62 \\
{[0.49]}\end{array}$ & $\begin{array}{c}0.33 \\
{[0.47]}\end{array}$ & $\begin{array}{c}0.63 \\
{[0.49]}\end{array}$ \\
\hline Decatur*Dispute period & $\begin{array}{c}0.11 \\
{[0.32]}\end{array}$ & $\begin{array}{c}0.50 \\
{[0.50]}\end{array}$ & $\begin{array}{c}0.11 \\
{[0.32]}\end{array}$ & $\begin{array}{c}0.47 \\
{[0.50]}\end{array}$ \\
\hline $\mathrm{N}$ & 135 & 135 & 135 & 135 \\
\hline
\end{tabular}

Notes: Standard deviations in brackets. Weighted means are weighted by the number of claims (column 2) or complaints (column 4), thus giving the average characteristics of tires that failed. In column 2 there were 24 cells with a weight of zero (i.e., no claims), and in column 4 there were 43 cells with a weight of zero (i.e., no complaints.) Source: authors' calculations. 
Table 3: Poisson Regression Models for Number of Defective P235/75R15 Tires by Plant, Production Year and Calendar Year; Aggregate Analysis of ATX and Wilderness AT Tires

Dependent Variable:

Complaints, with imputations

$\underline{\text { Dependent Variable: Claims }}$

for missing values

Explanatory Variables:

(1)

(2)

(3)

(4)

(5)

(6)

\begin{tabular}{|c|c|c|c|c|c|c|}
\hline Constant & $\begin{array}{l}-8.71 \\
(2.15)\end{array}$ & $\begin{array}{l}-22.45 \\
(2.89)\end{array}$ & $\begin{array}{l}-18.69 \\
(3.62)\end{array}$ & $\begin{array}{l}-8.26 \\
(2.34)\end{array}$ & $\begin{array}{r}-15.60 \\
(1.78)\end{array}$ & $\begin{array}{l}-12.78 \\
(2.17)\end{array}$ \\
\hline Log Production & $\begin{array}{c}0.80 \\
(0.16)\end{array}$ & $\begin{array}{c}1.49 \\
(0.19)\end{array}$ & $\begin{array}{c}1.27 \\
(0.23)\end{array}$ & $\begin{array}{c}0.72 \\
(0.18)\end{array}$ & $\begin{array}{c}1.08 \\
(0.12)\end{array}$ & $\begin{array}{c}0.92 \\
(0.14)\end{array}$ \\
\hline Proportion ATX & & & $\begin{array}{c}0.19 \\
(0.85)\end{array}$ & & & $\begin{array}{c}0.52 \\
(0.49)\end{array}$ \\
\hline $\begin{array}{l}\text { Proportion Original } \\
\text { Equipment }\end{array}$ & & & $\begin{array}{l}-1.40 \\
(0.96)\end{array}$ & & & $\begin{array}{l}-1.58 \\
(0.65)\end{array}$ \\
\hline Age & & $\begin{array}{c}2.09 \\
(0.28)\end{array}$ & $\begin{array}{l}2.16 \\
(0.30)\end{array}$ & & $\begin{array}{c}1.17 \\
(0.13)\end{array}$ & $\begin{array}{c}1.22 \\
(0.13)\end{array}$ \\
\hline Age Squared & & $\begin{array}{l}-0.21 \\
(0.03)\end{array}$ & $\begin{array}{l}-0.21 \\
(0.04)\end{array}$ & & $\begin{array}{l}-0.11 \\
(0.02)\end{array}$ & $\begin{array}{l}-0.11 \\
(0.02)\end{array}$ \\
\hline Decatur (1=yes) & $\begin{array}{l}-0.14 \\
(0.36)\end{array}$ & $\begin{array}{c}1.31 \\
(0.44)\end{array}$ & $\begin{array}{c}0.65 \\
(0.58)\end{array}$ & $\begin{array}{l}-0.36 \\
(0.43)\end{array}$ & $\begin{array}{c}0.43 \\
(0.30)\end{array}$ & $\begin{array}{l}-0.15 \\
(0.38)\end{array}$ \\
\hline $\begin{array}{l}\text { Labor dispute } \\
\text { period ( } 1=\text { yes })\end{array}$ & $\begin{array}{l}-0.10 \\
(0.30)\end{array}$ & $\begin{array}{c}0.25 \\
(0.31)\end{array}$ & $\begin{array}{c}0.07 \\
(0.33)\end{array}$ & $\begin{array}{c}0.13 \\
(0.29)\end{array}$ & $\begin{array}{c}0.38 \\
(0.19)\end{array}$ & $\begin{array}{c}0.20 \\
(0.19)\end{array}$ \\
\hline Decatur*Dispute period & $\begin{array}{c}2.40 \\
(0.45)\end{array}$ & $\begin{array}{c}1.39 \\
(0.48)\end{array}$ & $\begin{array}{c}1.48 \\
(0.53)\end{array}$ & $\begin{array}{c}2.29 \\
(0.50)\end{array}$ & $\begin{array}{c}1.73 \\
(0.33)\end{array}$ & $\begin{array}{c}1.71 \\
(0.35)\end{array}$ \\
\hline $\begin{array}{l}\text { Mean Dep. Var. } \\
\text { [S.D.] }\end{array}$ & $\begin{array}{c}12.10 \\
{[29.37]}\end{array}$ & $\begin{array}{c}12.10 \\
{[29.37]}\end{array}$ & $\begin{array}{c}12.10 \\
{[29.37]}\end{array}$ & $\begin{array}{c}5.81 \\
{[10.88]}\end{array}$ & $\begin{array}{c}5.81 \\
{[10.88]}\end{array}$ & $\begin{array}{c}5.81 \\
{[10.88]}\end{array}$ \\
\hline $\begin{array}{l}\mathrm{N} \\
\text { Pseudo } \mathrm{R}^{2} \\
\text { Log Likelihood }\end{array}$ & $\begin{array}{c}135 \\
0.40 \\
-1417.21\end{array}$ & $\begin{array}{c}135 \\
0.81 \\
-452.82\end{array}$ & $\begin{array}{c}135 \\
0.82 \\
-436.66\end{array}$ & $\begin{array}{c}135 \\
0.42 \\
-559.28\end{array}$ & $\begin{array}{c}135 \\
0.68 \\
-304.93\end{array}$ & $\begin{array}{c}135 \\
0.69 \\
-294.43\end{array}$ \\
\hline
\end{tabular}

Notes: Robust standard errors in parentheses. Standard deviations of dependent variable in brackets. Dependent variable corresponds to incidents per year of production, plant of production and calendar year of failure. Incidents in the NHTSA data set (columns 4-6) correspond to reporting periods prior to August 2000, for failures occurring between January 1991 and December 1999. Incidents in the Firestone Claims data set (columns 1-3) occurred between January 1991 and December 1999 and claims were made before January 2000. Proportion Original Equipment denotes the proportion of tires produced in the cell that were original equipment for Ford, Mercury, or Mazda vehicles. Proportion ATX denotes the proportion of tires produced in the cell that were ATX tires. To adjust for incomplete reporting in the NHTSA data set, missing values were imputed by assigning values from other observations with complete data, conditional on available data. Ten imputed data sets were generated. Reported estimates were obtained by averaging the estimates derived from each imputed data set. Standard errors were calculated by taking the square root of the sum of the average sampling variance across data sets and the variance of the estimates across the ten imputed data sets (to account for variability due to imputation). Other summary statistics reported for columns 4-6 are the average of the estimates across the imputed data sets. 
Table 4: Negative Binomial Regression Models for Number of Defective P235/75R15 Tires by Plant, Production Year and Calendar Year; Aggregate Analysis of ATX and Wilderness AT Tires

\begin{tabular}{|c|c|c|c|c|c|c|}
\hline \multirow[b]{2}{*}{ Explanatory Variables: } & \multicolumn{3}{|c|}{$\begin{array}{c}\text { Dependent Variable: } \\
\text { Claims }\end{array}$} & \multicolumn{3}{|c|}{$\begin{array}{l}\text { Dependent Variable: } \\
\text { Complaints with imputations } \\
\text { for missing values }\end{array}$} \\
\hline & (1) & (2) & (3) & (4) & $(5)$ & $(6)$ \\
\hline Constant & $\begin{array}{l}-2.31 \\
(2.40)\end{array}$ & $\begin{array}{l}-19.95 \\
(2.11)\end{array}$ & $\begin{array}{l}-16.55 \\
(2.19)\end{array}$ & $\begin{array}{l}-6.50 \\
(2.24)\end{array}$ & $\begin{array}{l}-14.86 \\
(1.83)\end{array}$ & $\begin{array}{l}-11.62 \\
(2.12)\end{array}$ \\
\hline Log Production & $\begin{array}{c}0.35 \\
(0.18)\end{array}$ & $\begin{array}{c}1.34 \\
(0.14)\end{array}$ & $\begin{array}{l}1.15 \\
(0.14)\end{array}$ & $\begin{array}{c}0.59 \\
(0.17)\end{array}$ & $\begin{array}{c}1.04 \\
(0.13)\end{array}$ & $\begin{array}{c}0.86 \\
(0.14)\end{array}$ \\
\hline Proportion ATX & & & $\begin{array}{c}0.27 \\
(0.55)\end{array}$ & & & $\begin{array}{c}0.42 \\
(0.51)\end{array}$ \\
\hline $\begin{array}{l}\text { Proportion Original } \\
\text { Equipment }\end{array}$ & & & $\begin{array}{l}-1.71 \\
(0.72)\end{array}$ & & & $\begin{array}{l}-1.77 \\
(0.72)\end{array}$ \\
\hline Age & & $\begin{array}{c}1.91 \\
(0.17)\end{array}$ & $\begin{array}{c}2.01 \\
(0.18)\end{array}$ & & $\begin{array}{c}1.07 \\
(0.13)\end{array}$ & $\begin{array}{c}1.14 \\
(0.13)\end{array}$ \\
\hline Age Squared & & $\begin{array}{l}-0.19 \\
(0.02)\end{array}$ & $\begin{array}{l}-0.19 \\
(0.02)\end{array}$ & & $\begin{array}{l}-0.10 \\
(0.02)\end{array}$ & $\begin{array}{l}-0.10 \\
(0.02)\end{array}$ \\
\hline Decatur (1=yes) & $\begin{array}{l}-0.13 \\
(0.33)\end{array}$ & $\begin{array}{c}1.12 \\
(0.31)\end{array}$ & $\begin{array}{c}0.37 \\
(0.38)\end{array}$ & $\begin{array}{l}-0.04 \\
(0.33)\end{array}$ & $\begin{array}{c}0.43 \\
(0.30)\end{array}$ & $\begin{array}{l}-0.26 \\
(0.38)\end{array}$ \\
\hline Labor dispute period ( $1=$ yes $)$ & $\begin{array}{l}-0.17 \\
(0.29)\end{array}$ & $\begin{array}{c}0.24 \\
(0.21)\end{array}$ & $\begin{array}{l}-0.03 \\
(0.23)\end{array}$ & $\begin{array}{l}0.23 \\
(0.26)\end{array}$ & $\begin{array}{c}0.45 \\
(0.19)\end{array}$ & $\begin{array}{c}0.23 \\
(0.20)\end{array}$ \\
\hline Decatur*Dispute period & $\begin{array}{c}1.32 \\
(0.48)\end{array}$ & $\begin{array}{c}1.46 \\
(0.34)\end{array}$ & $\begin{array}{c}1.60 \\
(0.36)\end{array}$ & $\begin{array}{c}1.62 \\
(0.41)\end{array}$ & $\begin{array}{c}1.69 \\
(0.33)\end{array}$ & $\begin{array}{c}1.74 \\
(0.36)\end{array}$ \\
\hline $\begin{array}{l}\text { Mean Dep. Var. } \\
\text { [S.D] }\end{array}$ & $\begin{array}{c}12.10 \\
{[29.37]}\end{array}$ & $\begin{array}{c}12.10 \\
{[29.37]}\end{array}$ & $\begin{array}{c}12.10 \\
{[29.37]}\end{array}$ & $\begin{array}{c}5.81 \\
{[10.88]}\end{array}$ & $\begin{array}{c}5.81 \\
{[10.88]}\end{array}$ & $\begin{array}{c}5.81 \\
{[10.88]}\end{array}$ \\
\hline $\begin{array}{l}\text { N } \\
\text { Pseudo } \mathrm{R}^{2} \\
8 \\
\text { Log Likelihood }\end{array}$ & $\begin{array}{c}135 \\
0.02 \\
43.49 * \\
-391.44\end{array}$ & $\begin{array}{c}135 \\
0.23 \\
6.30 * \\
-307.89\end{array}$ & $\begin{array}{c}135 \\
0.24 \\
5.81 * \\
-303.40\end{array}$ & $\begin{array}{c}135 \\
0.07 \\
8.07 * \\
-335.29\end{array}$ & $\begin{array}{c}135 \\
0.23 \\
1.61 * \\
-277.30\end{array}$ & $\begin{array}{c}135 \\
0.25 \\
1.47^{*} \\
-270.45 \\
\end{array}$ \\
\hline $\begin{array}{l}\text { Notes: Standard errors in parentheses } \\
\text { incidents per year of production, plant } \\
\text { correspond to reporting periods prior } \\
\text { the Firestone Claims data set (column } \\
\text { 2000. Proportion Original Equipment } \\
\text { Mercury, or Mazda vehicles. Proporti } \\
\text { incomplete reporting in the NHTSA d } \\
\text { data, conditional on available data. Te } \\
\text { estimates derived from each imputed } \\
\text { sampling variance across data sets an } \\
\text { imputation). Other summary statistics } \\
\text { symbol } 8 \text { represents the scaling paran } \\
\text { the negative binomial model equals th } \\
\text { that we can reject the null hypothesis }\end{array}$ & $\begin{array}{l}\text { Standard de } \\
\text { f production } \\
\text { August } 200 \\
\text { 1-3) occurre } \\
\text { enotes the pr } \\
\text { ATX deno } \\
\text { a set, missin } \\
\text { imputed dat } \\
\text { ta set. Stan } \\
\text { he variance } \\
\text { eported for c } \\
\text { ter for the co } \\
\text { conditional } \\
\text { lat8 equals }\end{array}$ & $\begin{array}{l}\text { ns of depe } \\
\text { calendar ye } \\
\text { r failures oc } \\
\text { ween Janua } \\
\text { tion of tires } \\
\text { e proportio } \\
\text { lues were in } \\
\text { s were gene } \\
\text { errors were } \\
\text { e estimates } \\
\text { nns } 4-6 \text { are } \\
\text { ional varian } \\
\text { nce of the F } \\
\text { at a .05 leve }\end{array}$ & $\begin{array}{l}\text { t variable ir } \\
\text { ff failure. Ir } \\
\text { ring betwee } \\
1991 \text { and De } \\
\text { duced in th } \\
\text { tires produ } \\
\text { ted by assig } \\
\text { d. Reporte } \\
\text { culated by t } \\
\text { oss the ten i } \\
\text { average of } \\
n \text { the negati }\end{array}$ & $\begin{array}{l}\text { ket s. Depe } \\
\text { tts in the NH } \\
\text { dary } 1991 \text { an } \\
\text { er } 1999 \text { and } \\
\text { that were or } \\
\text { the cell tha } \\
\text { values from } \\
\text { nates were o } \\
\text { the square r } \\
\text { ed data sets } \\
\text { timates acro } \\
\text { lomial mode } \\
\text { 8 equals zer } \\
\text { ratio test. }\end{array}$ & $\begin{array}{l}\text { it variable cc } \\
\text { A data set }(c \\
\text { ecember } 195 \\
\text { ms were ma } \\
\text { al equipmen } \\
\text { re ATX tires } \\
\text { r observatio } \\
\text { ned by aver } \\
\text { of the sum o } \\
\text { ccount for v } \\
\text { te imputed d } \\
\text { he condition } \\
\text { tarred value }\end{array}$ & $\begin{array}{l}\text { ponds to } \\
\text { mns 4-6) } \\
\text { Incidents in } \\
\text { efore January } \\
\text { Ford, } \\
\text { o adjust for } \\
\text { jith complete } \\
\text { g the } \\
\text { average } \\
\text { bility due to } \\
\text { sets. The } \\
\text { ariance of } \\
8 \text { indicate }\end{array}$ \\
\hline
\end{tabular}


Table 5: Poisson Regression Models for Number of Defective P235/75R15 Tires by Tire Model (ATX or Wilderness), Plant, Production Year and Calendar Year; Pooled Sample

\begin{tabular}{|c|c|c|c|c|c|c|}
\hline \multirow[b]{2}{*}{ Explanatory Variables: } & \multicolumn{3}{|c|}{$\begin{array}{l}\text { Dependent Variable: } \\
\text { Claims }\end{array}$} & \multicolumn{3}{|c|}{$\begin{array}{l}\text { Dependent Variable: NHTSA } \\
\text { Complaints with imputations for } \\
\text { missing values }\end{array}$} \\
\hline & (1) & (2) & (3) & (4) & (5) & (6) \\
\hline Constant & $\begin{array}{l}-13.36 \\
(2.41)\end{array}$ & $\begin{array}{l}-25.57 \\
(3.31)\end{array}$ & $\begin{array}{l}-21.09 \\
(1.05)\end{array}$ & $\begin{array}{l}-9.38 \\
(2.52)\end{array}$ & $\begin{array}{l}-13.61 \\
(2.39)\end{array}$ & $\begin{array}{l}-11.35 \\
(2.01)\end{array}$ \\
\hline Log Production & $\begin{array}{c}1.15 \\
(0.18)\end{array}$ & $\begin{array}{c}1.72 \\
(0.06)\end{array}$ & $\begin{array}{c}1.44 \\
(0.25)\end{array}$ & $\begin{array}{c}0.79 \\
(0.19)\end{array}$ & $\begin{array}{c}0.94 \\
(0.17)\end{array}$ & $\begin{array}{c}0.80 \\
(0.14)\end{array}$ \\
\hline ATX (1=yes) & & & $\begin{array}{c}0.57 \\
(0.45)\end{array}$ & & & $\begin{array}{c}0.60 \\
(0.29)\end{array}$ \\
\hline $\begin{array}{l}\text { Proportion } \\
\text { Original Equipment }\end{array}$ & & & $\begin{array}{l}-1.64 \\
(0.22)\end{array}$ & & & $\begin{array}{l}-1.48 \\
(0.51)\end{array}$ \\
\hline Age & & $\begin{array}{c}2.07 \\
(0.28)\end{array}$ & $\begin{array}{c}2.12 \\
(0.29)\end{array}$ & & $\begin{array}{c}1.17 \\
(0.16)\end{array}$ & $\begin{array}{c}1.22 \\
(0.15)\end{array}$ \\
\hline Age Squared & & $\begin{array}{l}-0.20 \\
(0.01)\end{array}$ & $\begin{array}{l}-0.21 \\
(0.03)\end{array}$ & & $\begin{array}{l}-0.11 \\
(0.02)\end{array}$ & $\begin{array}{l}-0.11 \\
(0.02)\end{array}$ \\
\hline Decatur (1=yes) & $\begin{array}{l}-0.01 \\
(0.36)\end{array}$ & $\begin{array}{c}1.63 \\
(0.13)\end{array}$ & $\begin{array}{c}0.87 \\
(0.17)\end{array}$ & $\begin{array}{l}-0.36 \\
(0.45)\end{array}$ & $\begin{array}{c}0.29 \\
(0.39)\end{array}$ & $\begin{array}{l}-0.26 \\
(0.39)\end{array}$ \\
\hline Labor dispute period ( $1=\mathrm{yes})$ & $\begin{array}{l}-0.02 \\
(0.30)\end{array}$ & $\begin{array}{c}0.32 \\
(0.09)\end{array}$ & $\begin{array}{c}0.12 \\
(0.09)\end{array}$ & $\begin{array}{c}0.13 \\
(0.31)\end{array}$ & $\begin{array}{c}0.34 \\
(0.25)\end{array}$ & $\begin{array}{c}0.17 \\
(0.22)\end{array}$ \\
\hline Decatur*Dispute period & $\begin{array}{c}2.32 \\
(0.45)\end{array}$ & $\begin{array}{c}1.26 \\
(0.14)\end{array}$ & $\begin{array}{l}1.25 \\
(0.50)\end{array}$ & $\begin{array}{l}2.27 \\
(0.52)\end{array}$ & $\begin{array}{c}1.82 \\
(0.41)\end{array}$ & $\begin{array}{c}1.81 \\
(0.37)\end{array}$ \\
\hline $\begin{array}{l}\text { Mean Dep. Var. } \\
\text { [S.D.] }\end{array}$ & $\begin{array}{c}9.96 \\
{[25.62]}\end{array}$ & $\begin{array}{c}9.96 \\
{[25.62]}\end{array}$ & $\begin{array}{c}9.96 \\
{[25.62]}\end{array}$ & $\begin{array}{c}4.61 \\
{[8.68]}\end{array}$ & $\begin{array}{c}4.61 \\
{[8.68]}\end{array}$ & $\begin{array}{c}4.61 \\
{[8.68]}\end{array}$ \\
\hline $\mathrm{N}$ & 164 & 164 & 164 & 164 & 164 & 164 \\
\hline $\begin{array}{l}\text { Pseudo R } \\
\text { Log Likelihood }\end{array}$ & $\begin{array}{c}0.42 \\
-1483.96\end{array}$ & $\begin{array}{c}0.81 \\
-490.20\end{array}$ & $\begin{array}{c}0.82 \\
-461.93\end{array}$ & $\begin{array}{c}0.40 \\
-591.45\end{array}$ & $\begin{array}{c}0.66 \\
-339.36\end{array}$ & $\begin{array}{c}0.67 \\
-323.08\end{array}$ \\
\hline $\begin{array}{l}\text { Notes: Robust standard errors in pare } \\
\text { to incidents per year of production, } \mathrm{p} \\
\text { units of production were dropped. In } \\
2000 \text {, for failures occurring between } \\
\text { occurred between January } 1991 \text { and I } \\
\text { denotes the proportion of tires produc } \\
\text { incomplete reporting in the NHTSA } \\
\text { data, conditional on available data. T } \\
\text { estimates derived from each imputed } \\
\text { sampling variance across data sets an } \\
\text { imputation). Other summary statistic }\end{array}$ & $\begin{array}{l}\text { nt of producti } \\
\text { dents in the N } \\
\text { nuary } 1991 \text { ar } \\
\text { ecember } 1999 \\
\text { d in the cell th } \\
\text { ta set, missins } \\
\text { imputed data } \\
\text { ata set. Stand } \\
\text { the variance } \\
\text { reported for c }\end{array}$ & $\begin{array}{l}\text { tire model, a } \\
\text { SA data set } \\
\text { December } 19 \\
\text { d claims wer } \\
\text { were original } \\
\text { lues were im } \\
\text { ts were gene } \\
\text { errors were }\end{array}$ & $\begin{array}{l}\text { ependent va } \\
\text { calendar ye } \\
\text { lumns 4-6) } \\
\text { Incidents i } \\
\text { nade before } \\
\text { uipment for } \\
\text { ted by assig } \\
\text { ed. Reportec } \\
\text { culated by to }\end{array}$ & $\begin{array}{l}\text { in brackets. } \\
\text { failure. Cell } \\
\text { spond to rep } \\
\text { Firestone } \mathrm{Cl} \\
\text { ary } 2000 \text {. Pr } \\
\text {, Mercury, o } \\
\text { values from } \\
\text { mates were }\end{array}$ & $\begin{array}{l}\text { ependent va } \\
\text { rrespondin } \\
\text { ng periods } \\
\text { is data set (c } \\
\text { rtion Origir } \\
\text { azda vehicl } \\
\text { er observati } \\
\text { ined by ave } \\
\text { of the sum }\end{array}$ & $\begin{array}{l}\text { le corresponds } \\
\text { less than } 200 \\
\text { to August } \\
\text { mns 1-3) } \\
\text { quipment } \\
\text { To adjust for } \\
\text { with complete } \\
\text { ng the } \\
\text { le average } \\
\text { bility due to } \\
\text { sets. }\end{array}$ \\
\hline
\end{tabular}


Table 6: Poisson Regression Models for Number of Incidents with Defective Tires, By Type of Accident, NHTSA Complaints Data; Full Reporting Period Aggregate Analysis of ATX and Wilderness AT Tires;

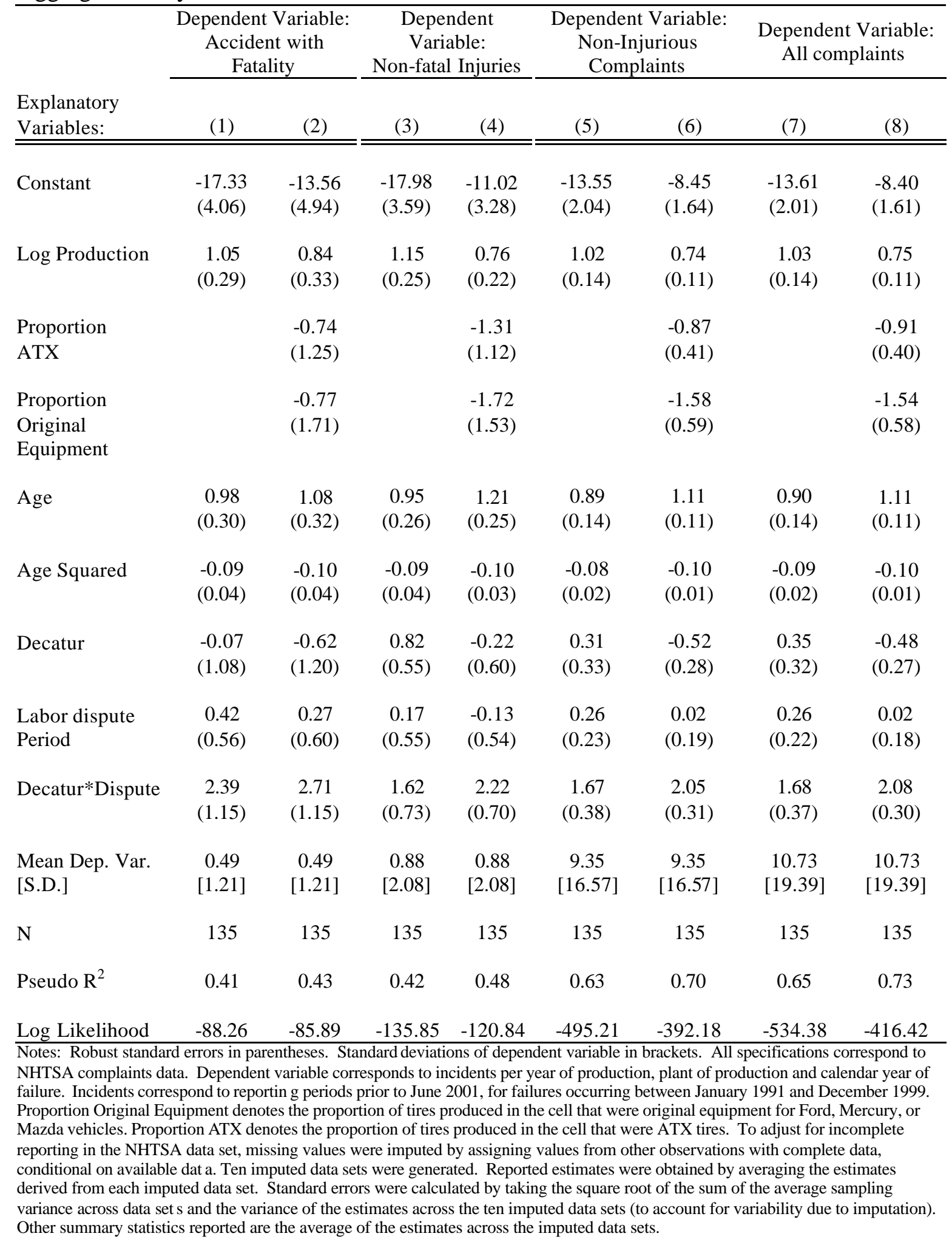


Table 7: High-Speed Stress Test Results: OLS Estimates

Dependent Variable: Miles Traveled to Burst

\begin{tabular}{|c|c|c|c|c|c|c|}
\hline $\begin{array}{l}\text { Explanatory } \\
\text { Variables: }\end{array}$ & $\begin{array}{l}\text { Means: } \\
\text { Full Sample }\end{array}$ & $\begin{array}{l}\text { Full Sample } \\
\begin{array}{c}(1) \\
\end{array}\end{array}$ & $\begin{array}{c}1994-1998 \\
(2) \\
\end{array}$ & $\begin{array}{r}1995-1998 \\
(3) \\
\end{array}$ & $\begin{array}{l}\text { No Pre- } \\
\text { Production } \\
\text { Tires } \\
(4) \\
\end{array}$ & $\begin{array}{c}\text { No Pre- } \\
\text { Production } \\
\text { Tires, } \\
\text { 1995-1998 } \\
\text { (5) } \\
\end{array}$ \\
\hline Constant & & $\begin{array}{r}108.83 \\
(2.30)\end{array}$ & $\begin{array}{r}110.16 \\
(2.65)\end{array}$ & $\begin{array}{r}110.16 \\
(2.66)\end{array}$ & $\begin{array}{c}108.83 \\
(2.37)\end{array}$ & $\begin{array}{c}110.16 \\
(2.86)\end{array}$ \\
\hline Decatur (1=yes) & $\begin{array}{c}0.47 \\
{[0.50]}\end{array}$ & $\begin{array}{c}2.13 \\
(3.72)\end{array}$ & $\begin{array}{l}1.57 \\
(4.18)\end{array}$ & $\begin{array}{c}1.99 \\
(4.22)\end{array}$ & $\begin{array}{l}-0.63 \\
(4.37)\end{array}$ & $\begin{array}{l}-1.41 \\
(5.25)\end{array}$ \\
\hline $\begin{array}{l}\text { Dispute period } \\
(1=\text { yes })\end{array}$ & $\begin{array}{c}0.61 \\
{[0.49]}\end{array}$ & $\begin{array}{l}4.93 \\
(3.36)\end{array}$ & $\begin{array}{c}3.74 \\
(3.66)\end{array}$ & $\begin{array}{c}4.61 \\
(3.92)\end{array}$ & $\begin{array}{c}4.88 \\
(3.91)\end{array}$ & $\begin{array}{c}5.34 \\
(4.87)\end{array}$ \\
\hline $\begin{array}{l}\text { Decatur*Dispute } \\
\text { period }\end{array}$ & $\begin{array}{c}0.30 \\
{[0.46]}\end{array}$ & $\begin{array}{l}-16.85 \\
(4.80)\end{array}$ & $\begin{array}{c}-16.34 \\
(5.22)\end{array}$ & $\begin{array}{l}-17.29 \\
(5.43)\end{array}$ & $\begin{array}{c}-12.63 \\
(5.96)\end{array}$ & $\begin{array}{c}-13.64 \\
(7.13)\end{array}$ \\
\hline $\begin{array}{l}\text { Pre-Production } \\
\text { Models }\end{array}$ & $\begin{array}{c}0.35 \\
{[0.48]}\end{array}$ & $\begin{array}{l}-1.19 \\
(2.55)\end{array}$ & $\begin{array}{l}-1.43 \\
(2.64)\end{array}$ & $\begin{array}{l}-2.31 \\
(2.81)\end{array}$ & & \\
\hline $\begin{array}{l}\text { Mean Dep. Var. } \\
\text { [S.D.] }\end{array}$ & $\begin{array}{l}107.28 \\
{[12.57]}\end{array}$ & $\begin{array}{l}107.28 \\
{[12.57]}\end{array}$ & $\begin{array}{l}107.48 \\
{[12.97]}\end{array}$ & $\begin{array}{l}107.07 \\
{[13.08]}\end{array}$ & $\begin{array}{l}107.28 \\
{[12.35]}\end{array}$ & $\begin{array}{l}107.49 \\
{[13.37]}\end{array}$ \\
\hline $\mathrm{N}$ & & 105 & 98 & 90 & 68 & 57 \\
\hline $\mathrm{R}^{2}$ & & 0.23 & 0.24 & 0.25 & 0.15 & 0.18 \\
\hline F-stat & & 7.40 & 7.31 & 7.00 & 3.90 & 3.82 \\
\hline
\end{tabular}

Notes: Standard errors in parentheses. Standard deviations in brackets. Years refer to years of production. 
Table 8: Poisson Regression Model for Non-P235/75R15 Firestone Tires Under NHTSA EA00-023 Investigation

Dependent Variable: Number of Complaints with imputations for missing values

Constant

$-38.37$

$-14.60$

(9.21)

(0.31)

Log Total NonP235

15.49

2.49

$1^{\wedge}$

Tires Produced

[0.45]

(0.58)

Age

0.35

0.28

[2.22]

(0.26)

(0.26)

Age Squared

12

$-0.08$

$-0.08$

[15.47]

(0.05)

(0.05)

Decatur

0.33

$-0.87$

$-1.12$

[0.47]

(0.57)

(0.54)

Dispute

0.33

$-0.48$

$-0.19$

[0.47]

(0.39)

(0.35)

Decatur*Dispute

0.11

1.98

1.34

[0.32]

(0.80)

(0.74)

Mean Dep. Var.

[S.D.]

[5.14]

[5.14]

[5.14]

N

135

135

135

Pseudo $\mathrm{R}^{2}$

0.33

0.26

Log Likelihood

$-339.44$

$-376.79$

Notes: Robust Standard errors in parentheses. Standard deviations of dependent variable in brackets. All specifications use NHTSA complaints data. Dependent variable corresponds to incidents per year of production, plant of production and calendar year of failure. Incidents correspond to reporting periods prior to August 2000, for failures occurring between January 1991 and December 1999. To adjust for incomplete reporting in the NHTSA data set, missing values were imputed by assigning values from other observations with complete data, conditional on available data; tire size was not imputed, however. Ten imputed data sets were generated. Reported estimates were obtained by averaging the estimates derived from each imputed data set. Standard errors were calculated by taking the square root of the sum of the average sampling variance across data sets and the variance of the estimates across the ten imputed data sets (to account for variability due to imputation). Other summary statistics reported are the average of the estimates across the imputed data sets. The specifications in column (2) constrains the coefficient of log production to one.

${ }^{\wedge}$ Coefficient constrained to one. 
Table A1: Summary of Missing Values

\begin{tabular}{|c|c|c|c|c|c|c|}
\hline Missing: & & $\begin{array}{l}\text { All Reporting } \\
\text { Periods, } \\
\text { All Tire Sizes } \\
\end{array}$ & $\begin{array}{c}\text { Reported Before } \\
\text { Recall, } \\
\text { All Tire Sizes }\end{array}$ & $\begin{array}{c}\text { Reported After } \\
\text { Recall, All Tire } \\
\text { Sizes } \\
\end{array}$ & $\begin{array}{l}\text { All Reporting } \\
\text { Periods, } \\
\text { P235/75R15 } \\
\text { Tires } \\
\end{array}$ & $\begin{array}{c}\text { Reported Before } \\
\text { Recall, } \\
\text { P235/75R15 } \\
\text { Tires } \\
\end{array}$ \\
\hline None & 1 & 780 & 186 & 594 & 443 & 180 \\
\hline YR, MR & 2 & 31 & N/A & N/A & 28 & 0 \\
\hline $\mathrm{F}$ & 3 & 55 & 5 & 50 & 19 & 4 \\
\hline YR, MR, F & 4 & 4 & N/A & N/A & 3 & N/A \\
\hline YP & 5 & 468 & 20 & 448 & 261 & 19 \\
\hline YP, YR, MR & 6 & 6 & N/A & N/A & 6 & 190 \\
\hline YP, F & 7 & 68 & 0 & 68 & 37 & N/A \\
\hline YP, F, YR, MR & 8 & 1 & N/A & N/A & 0 & N/A \\
\hline PL & 9 & 5 & 0 & 5 & 1 & 0 \\
\hline PL, YP & 10 & 1285 & 218 & 1067 & 646 & 0 \\
\hline PL, YP, YR, MR & 11 & 28 & N/A & N/A & 22 & N/A \\
\hline PL, YP, F & 12 & 269 & 9 & 260 & 111 & 6 \\
\hline PL, YP, F, MR & 13 & 1 & 0 & 1 & 1 & 0 \\
\hline PL, YP, F, YR & 14 & 2 & N/A & N/A & 2 & N/A \\
\hline PL, YP, F, YR, MR & 15 & 6 & N/A & N/A & 133 & N/A \\
\hline $\mathrm{TM}$ & 16 & 151 & 126 & 25 & 4 & 125 \\
\hline TM, YR, MR & 17 & 5 & N/A & N/A & 3 & N/A \\
\hline TM, F & 18 & 9 & 0 & 9 & 17 & 0 \\
\hline TM, YP & 19 & 23 & 8 & 15 & 1 & 8 \\
\hline TM, YP, F & 20 & 1 & 1 & 0 & 2 & 1 \\
\hline TM, PL & 21 & 3 & 2 & 1 & 172 & 2 \\
\hline TM, PL, YP & 22 & 245 & 157 & 88 & 14 & 150 \\
\hline TM, PL, YP, YR, MR & 23 & 17 & N/A & N/A & 14 & N/A \\
\hline TM, PL, YP, F & 24 & 44 & 4 & 40 & 0 & 4 \\
\hline TS & 25 & 95 & 22 & 73 & N/A & N/A \\
\hline TS, YR, MR & 26 & 3 & N/A & N/A & N/A & N/A \\
\hline $\mathrm{TS}, \mathrm{F}$ & 27 & 6 & 1 & 5 & N/A & N/A \\
\hline TS, YP & 28 & 69 & 2 & 67 & N/A & N/A \\
\hline TS, YP, F & 29 & 14 & 0 & 14 & N/A & N/A \\
\hline TS, PL & 30 & 3 & 1 & 2 & N/A & N/A \\
\hline TS, PL, YP & 31 & 793 & 85 & 708 & N/A & N/A \\
\hline TS, PL. YP, YR & 32 & 1 & N/A & N/A & N/A & N/A \\
\hline TS, PL. YP, YR, MR & 33 & 13 & N/A & N/A & N/A & N/A \\
\hline TS, PL, YP, F & 34 & 260 & 14 & 246 & N/A & N/A \\
\hline TS, PL, YP, F, YR, MR & 35 & 3 & N/A & N/A & N/A & N/A \\
\hline $\mathrm{TS}, \mathrm{TM}$ & 36 & 11 & 7 & 4 & N/A & N/A \\
\hline TS, TM, F & 37 & 1 & 0 & 1 & N/A & N/A \\
\hline TS, TM, F, YR, MR & 38 & 1 & N/A & N/A & N/A & N/A \\
\hline
\end{tabular}

Continued - 
Table A1: Summary of Missing Values (cont.)

\begin{tabular}{|c|c|c|c|c|c|c|}
\hline Missing: & & $\begin{array}{l}\text { All Reporting } \\
\text { Periods, } \\
\text { All Tire Sizes } \\
\end{array}$ & $\begin{array}{c}\text { Reported Before } \\
\text { Recall, } \\
\text { All Tire Sizes }\end{array}$ & $\begin{array}{l}\text { Reported After } \\
\text { Recall, All Tire } \\
\text { Sizes } \\
\end{array}$ & $\begin{array}{l}\text { All Reporting } \\
\text { Periods, } \\
\text { P235/75R15 } \\
\text { Tires } \\
\end{array}$ & $\begin{array}{c}\text { Reported Before } \\
\text { Recall, } \\
\text { P235/75R15 } \\
\text { Tires } \\
\end{array}$ \\
\hline TS, TM, YP & 39 & 2 & 0 & 2 & N/A & N/A \\
\hline TS, TM, PL, YP & 40 & 304 & 121 & 183 & N/A & N/A \\
\hline TS, TM, PL, YP, YR, MR & 41 & 17 & N/A & N/A & N/A & N/A \\
\hline TS, TM, PL, YP, F & 42 & 85 & 5 & 80 & N/A & N/A \\
\hline All & 43 & 1 & N/A & N/A & N/A & N/A \\
\hline None & & 780 & 186 & 594 & 443 & 180 \\
\hline One & & 774 & 173 & 601 & 414 & 148 \\
\hline Two & & 1508 & 239 & 1238 & 733 & 200 \\
\hline Three & & 1343 & 252 & 1073 & 297 & 157 \\
\hline Four & & 641 & 139 & 470 & 37 & 4 \\
\hline Five & & 122 & 5 & 80 & 16 & N/A \\
\hline Six & & 20 & N/A & N/A & 0 & N/A \\
\hline Seven & & 1 & N/A & N/A & N/A & N/A \\
\hline
\end{tabular}


Table A2: Summary of Conditioning Variables for Imputation Procedure

\begin{tabular}{|c|c|c|c|c|}
\hline & & P235/75R15 Data set & \multicolumn{2}{|c|}{ Non-P235/75R15 Data set } \\
\hline 0 oservaturis & & & & \\
\hline $\begin{array}{l}\text { Missing: } \\
\text { None }\end{array}$ & 1 & N/A & & N/A \\
\hline YR, MR & 2 & F, YP(1) & $\mathrm{F}$ & \\
\hline $\mathrm{F}$ & 3 & YP(1) & $\mathrm{YP}(3), \mathrm{YR}$ & \\
\hline YR, MR, F & 4 & YP(1) & $\mathrm{YP}(3)$ & \\
\hline YP & 5 & VY, VM & VY, VM & \\
\hline YP, YR, MR & 6 & $\mathrm{~F}$ & & N/A \\
\hline YP, F & 7 & TM, YR & TM, YR & \\
\hline YP, F, YR, MR & 8 & TM & TM & \\
\hline $\mathrm{PL}$ & 9 & TM & $\mathrm{YP}(3)$ & \\
\hline $\mathrm{PL}, \mathrm{YP}$ & 10 & VY, VM & VY, VM & \\
\hline PL, YP, YR, MR & 11 & $\mathrm{~F}$ & TM & \\
\hline PL, YP, F & 12 & VY, YR & VY, YR & \\
\hline PL, YP, F, MR & 13 & TM, YR & YR & \\
\hline PL, YP, F, YR & 14 & TS & TM & \\
\hline PL, YP, F, YR, MR & 15 & TS & TM & \\
\hline TM & 16 & PL, YP(2) & $\mathrm{PL}, \mathrm{YP}(2)$ & \\
\hline TM, YR, MR & 17 & TS & $\mathrm{F}$ & \\
\hline TM, F & 18 & $\mathrm{YP}(1)$ & $\mathrm{YP}(3)$ & \\
\hline TM, YP & 19 & VY, VM & $\mathrm{F}$ & \\
\hline TM, YP, F & 20 & VY, YR & TM, PL & \\
\hline TM, PL & 21 & TS & $\mathrm{YP}(2)$ & \\
\hline TM, PL, YP & 22 & VY, VM & VY, VM & \\
\hline TM, PL, YP, YR, MR & 23 & VY & $\mathrm{F}$ & \\
\hline TM, PL, YP, F & 24 & TS, YR & YR & \\
\hline TS & 25 & TM, EX & & N/A \\
\hline TS, YR, MR & 26 & EX, F & & N/A \\
\hline $\mathrm{TS}, \mathrm{F}$ & 27 & EX, YP(2) & & N/A \\
\hline $\mathrm{TS}, \mathrm{YP}$ & 28 & $\mathrm{VY}, \mathrm{VM}, \mathrm{EX}$ & & N/A \\
\hline $\mathrm{TS}, \mathrm{YP}, \mathrm{F}$ & 29 & VY, VM & & N/A \\
\hline TS, $\mathrm{PL}$ & 30 & TM, EX & & N/A \\
\hline TS, PL, YP & 31 & VY, VM & & N/A \\
\hline TS, PL. YP, YR & 32 & VY, VM & & N/A \\
\hline TS, PL. YP, YR, MR & 33 & VY, VM & & N/A \\
\hline TS, PL, YP, F & 34 & VY, VM & & N/A \\
\hline TS, PL, YP, F, YR, MR & 35 & TM & & N/A \\
\hline TS, TM & 36 & EX, YP(3) & & N/A \\
\hline TS, TM, F & 37 & YP(1), YR & & N/A \\
\hline TS, TM, F, YR, MR & 38 & PL & & N/A \\
\hline
\end{tabular}

Continued - 
Table A2: Summary of Conditioning Variables (cont.)

\begin{tabular}{|l|l|l|l|}
\hline TS, TM, YP & 39 & VY, VM & N/A \\
TS, TM, PL, YP & 40 & VY, VM & N/A \\
TS, TM, PL, YP, YR, MR & 41 & F & N/A \\
TS, TM, PL, YP, F & 42 & YR & N/A \\
All & 43 & None & N/A \\
\hline
\end{tabular}

TS $=$ Tire Size,

$\mathrm{TM}=$ Tire Model,

MR $=$ Month of Report,

$\mathrm{PL}=$ Plant

$\mathrm{F}=$ Ford Vehicle (1=yes)

EX $=$ Explorer $(1=$ yes $)$

F = Year of Failure with cut-points at 1991,1994,1997,2000.

YP(1) = Year of Production with cut-points at 0,1990,1992,1994,1996,1998,2000.

YP(2) = Year of Production with cut-points at 1996

YP(3) = Year of Production with cut-points at 1990, 1994, 1996, 1998.

YR $=$ Year reported with cut -points at 1991,1995,2000.

$\mathrm{VM}=$ Vehicle miles with cut-points at 15000,30000,60000,90000.

$\mathrm{VY}=$ Vehicle year with cut - points at 1994,1997,2000. 
Table A3: Poisson Regression Models for Number of Incidents with Defective Tires, by Type of Accident, NHTSA Complaints Data; Full Reporting Period without Imputing Missing Data (Robust Standard Errors)

Aggregate Analysis of ATX and Wilderness AT Tires

\begin{tabular}{|c|c|c|c|c|c|c|c|c|}
\hline \multirow[b]{2}{*}{$\begin{array}{l}\text { Explanatory } \\
\text { Variables }\end{array}$} & \multicolumn{2}{|c|}{$\begin{array}{c}\text { Dependent Variable: } \\
\text { Accident with } \\
\text { Fatality } \\
\end{array}$} & \multicolumn{2}{|c|}{$\begin{array}{c}\text { Dependent } \\
\text { Variable: } \\
\text { Non-fatal Injuries }\end{array}$} & \multicolumn{2}{|c|}{$\begin{array}{l}\text { Dependent Variable: } \\
\text { All other complaints }\end{array}$} & \multicolumn{2}{|c|}{$\begin{array}{l}\text { Dependent Variable: } \\
\text { All complaints }\end{array}$} \\
\hline & $(1)$ & $(2)$ & (3) & (4) & $(5)$ & $(6)$ & (7) & $(8)$ \\
\hline Constant & $\begin{array}{l}-19.03 \\
(4.75)\end{array}$ & $\begin{array}{l}-17.58 \\
(6.12)\end{array}$ & $\begin{array}{l}-19.23 \\
(4.29)\end{array}$ & $\begin{array}{l}-13.37 \\
(4.60)\end{array}$ & $\begin{array}{l}-20.11 \\
(2.90)\end{array}$ & $\begin{array}{l}-14.72 \\
(3.03)\end{array}$ & $\begin{array}{l}-19.20 \\
(2.45)\end{array}$ & $\begin{array}{l}-14.14 \\
(2.69)\end{array}$ \\
\hline Log Production & $\begin{array}{c}1.09 \\
(0.33)\end{array}$ & $\begin{array}{c}1.01 \\
(0.40)\end{array}$ & $\begin{array}{c}1.15 \\
(0.30)\end{array}$ & $\begin{array}{c}0.81 \\
(0.31)\end{array}$ & $\begin{array}{c}1.26 \\
(0.20)\end{array}$ & $\begin{array}{c}0.95 \\
(0.20)\end{array}$ & $\begin{array}{c}1.23 \\
(0.17)\end{array}$ & $\begin{array}{c}0.94 \\
(0.18)\end{array}$ \\
\hline Proportion ATX & & $\begin{array}{l}-0.08 \\
(1.51)\end{array}$ & & $\begin{array}{l}-0.78 \\
(1.16)\end{array}$ & & $\begin{array}{c}0.12 \\
(0.76)\end{array}$ & & $\begin{array}{l}-0.05 \\
(0.67)\end{array}$ \\
\hline $\begin{array}{l}\text { Original } \\
\text { Equipment }\end{array}$ & & $\begin{array}{l}-0.40 \\
(1.72)\end{array}$ & & $\begin{array}{l}-1.37 \\
(1.55)\end{array}$ & & $\begin{array}{l}-2.12 \\
(0.96)\end{array}$ & & $\begin{array}{l}-1.82 \\
(0.85)\end{array}$ \\
\hline Age & $\begin{array}{c}1.23 \\
(0.36)\end{array}$ & $\begin{array}{c}1.26 \\
(0.38)\end{array}$ & $\begin{array}{c}1.04 \\
(0.32)\end{array}$ & $\begin{array}{c}1.20 \\
(0.33)\end{array}$ & $\begin{array}{c}1.59 \\
(0.24)\end{array}$ & $\begin{array}{c}1.73 \\
(0.25)\end{array}$ & $\begin{array}{c}1.47 \\
(0.20)\end{array}$ & $\begin{array}{c}1.60 \\
(0.21)\end{array}$ \\
\hline Age Squared & $\begin{array}{l}-0.11 \\
(0.05)\end{array}$ & $\begin{array}{l}-0.11 \\
(0.05)\end{array}$ & $\begin{array}{l}-0.09 \\
(0.04)\end{array}$ & $\begin{array}{l}-0.10 \\
(0.04)\end{array}$ & $\begin{array}{l}-0.14 \\
(0.03)\end{array}$ & $\begin{array}{l}-0.15 \\
(0.03)\end{array}$ & $\begin{array}{l}-0.13 \\
(0.03)\end{array}$ & $\begin{array}{l}-0.14 \\
(0.03)\end{array}$ \\
\hline Decatur & $\begin{array}{l}-0.39 \\
(1.07)\end{array}$ & $\begin{array}{l}-0.61 \\
(1.26)\end{array}$ & $\begin{array}{c}1.13 \\
(0.63)\end{array}$ & $\begin{array}{c}0.27 \\
(0.73)\end{array}$ & $\begin{array}{c}0.63 \\
(0.50)\end{array}$ & $\begin{array}{l}-0.35 \\
(0.57)\end{array}$ & $\begin{array}{c}0.65 \\
(0.42)\end{array}$ & $\begin{array}{l}-0.23 \\
(0.49)\end{array}$ \\
\hline $\begin{array}{l}\text { Labor dispute } \\
\text { Period }\end{array}$ & $\begin{array}{c}0.04 \\
(0.59)\end{array}$ & $\begin{array}{l}-0.03 \\
(0.63)\end{array}$ & $\begin{array}{l}-0.06 \\
(0.61)\end{array}$ & $\begin{array}{l}-0.31 \\
(0.62)\end{array}$ & $\begin{array}{c}0.60 \\
(0.31)\end{array}$ & $\begin{array}{c}0.33 \\
(0.31)\end{array}$ & $\begin{array}{c}0.50 \\
(0.27)\end{array}$ & $\begin{array}{c}0.25 \\
(0.28)\end{array}$ \\
\hline Decatur*Dispute & $\begin{array}{c}3.07 \\
(1.16)\end{array}$ & $\begin{array}{c}3.14 \\
(1.23)\end{array}$ & $\begin{array}{c}1.68 \\
(0.81)\end{array}$ & $\begin{array}{c}2.09 \\
(0.85)\end{array}$ & $\begin{array}{c}1.69 \\
(0.54)\end{array}$ & $\begin{array}{c}1.86 \\
(0.54)\end{array}$ & $\begin{array}{c}1.74 \\
(0.46)\end{array}$ & $\begin{array}{c}1.93 \\
(0.47)\end{array}$ \\
\hline $\begin{array}{l}\text { Mean Dep. Var. } \\
\text { [S.D.] }\end{array}$ & $\begin{array}{c}0.27 \\
{[0.76]}\end{array}$ & $\begin{array}{c}0.27 \\
{[0.76]}\end{array}$ & $\begin{array}{c}0.33 \\
{[0.86]}\end{array}$ & $\begin{array}{c}0.33 \\
{[0.86]}\end{array}$ & $\begin{array}{c}2.33 \\
{[5.77]}\end{array}$ & $\begin{array}{c}2.33 \\
{[5.77]}\end{array}$ & $\begin{array}{c}2.94 \\
{[6.95]}\end{array}$ & $\begin{array}{c}2.94 \\
{[6.95]}\end{array}$ \\
\hline $\mathrm{N}$ & 135 & 135 & 135 & 135 & 135 & 135 & 135 & 135 \\
\hline Pseudo $\mathrm{R}^{2}$ & 0.40 & 0.40 & 0.35 & 0.37 & 0.62 & 0.64 & 0.64 & 0.66 \\
\hline Log Likelihood & -58.80 & -58.74 & -73.41 & -71.43 & -205.54 & -195.77 & -227.09 & -216.45 \\
\hline
\end{tabular}

